\title{
GIS-based assessment of groundwater quality for drinking and irrigation purposes in central Iraq
}

Zaid F. Makki

Ali Adel Zuhaira

Sama M. Al-Jubouri

Rwayda Kh. S. Al-Hamd

Lee S. Cunningham

This is a post-peer-review, pre-copyedit version of an article published in Environmental Monitoring and Assessment.

The final authenticated version is available online at:

http://dx.doi.org/10.1007/s10661-021-08858-w 
GIS-based assessment of groundwater quality for drinking and irrigation purposes in central Iraq

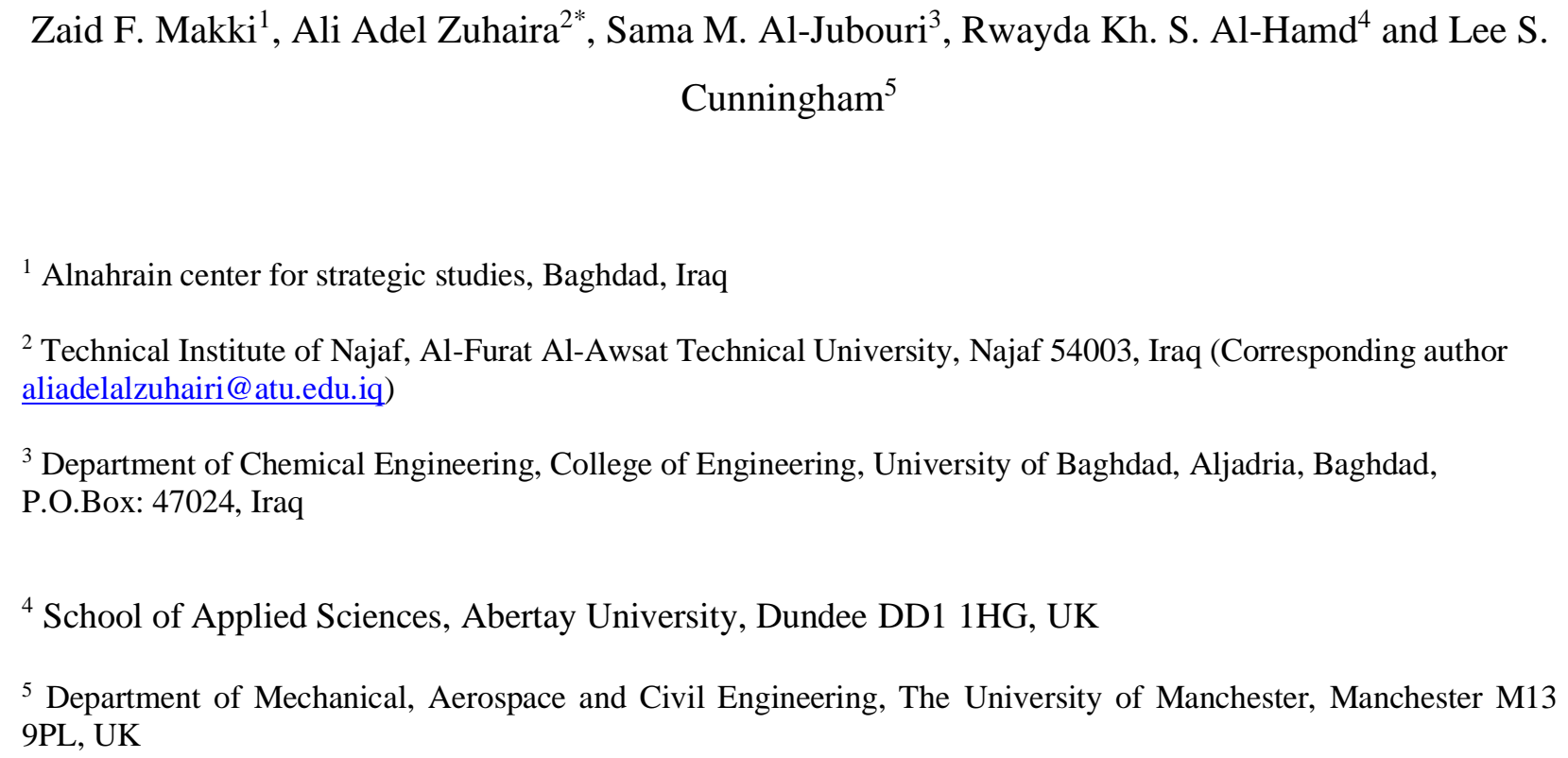


In many parts of the world, groundwater is considered to be a key source of fresh water for both the domestic and non-domestic sectors. Where groundwater extraction is implemented, systems to monitor water quality must ensure a safe and sustainable supply. Over the years, Iraq has suffered from surface water quality and supply problems, necessitating groundwater extraction in many regions. This study investigates groundwater quality in a region of central Iraq around Babylon city, covering an area of $5119 \mathrm{~km}^{2}$. The data gathered for this study included maps, well locations and water quality data and was sourced from the relevant governmental departments. A base map of the focussed region was initially prepared following data collection. The analysed water quality parameters were used as an attribute database to produce thematic maps using a geographical information system (GIS) environment. In this paper, the Water Quality Index (WQI) and the Irrigation Water Quality Index (IWQI) were calculated for different groundwater samples using various parameters including the Electrical Conductivity (EC), $\mathrm{Cl}^{-}, \mathrm{HCO}^{-}, \mathrm{Na}^{+}$and $\mathrm{pH}$. Moreover, the groundwater suitability for irrigation purposes has been assessed using indices such as Kelly's Ratio (KR), Sodium Absorption Ratio (SAR), Residual Sodium Carbonate (RSC), Soluble Sodium Percentage (SSP) and Permeability Index (PI). Water Quality Indices maps have been developed using the GIS environment. The obtained results reveal that the groundwater in the study location requires specific treatments to be usable. Keywords: Groundwater quality; Geographic Information System; Remote Sensing Water Quality Index and Irrigation Water Quality Index

\section{Declarations}

Funding: No fund was received for conducting this study.

Conflicts of Interest: The authors declare no conflict of interest.

Availability of data and material: Materials presented in this manuscript are available upon request from the authors.

73 Code availability: Not applicable

\section{Introduction}

The availability of useable water is a major global challenge and particularly prevalent in developing countries. Population growth and an increase in industrial activities raise water demand. Simultaneously, these continuous activities increase the mass of wastewater returned to the environment, resulting in pollution of water bodies and useable water scarcity (Al-Jubouri and Holmes (2020); Mohammed et al. (2007)). Surface water is strongly connected to groundwater; therefore, any changes to surface water directly affect groundwater (Bachmann et al., 2019). Moreover, there is an extremely complex relation between rainfall, surface water and water supply contamination. An additional impacting factor is the decrease in river flow due to reduced rainfall which affects ability to dilute effluents and increase pathogen or chemical loading. The water scarcity problem can be managed by 
bodies. At the same time, alternative water resources could also be sought. The pollutants present in wastewaters have to be identified to be effectively treated and removed. The pollutant type and concentration are the most critical factors determining the treatment method and the process's cost and performance.

Given the issues mentioned above, increasing accessibility to alternative water resources can significantly alleviate water scarcity (Nelly and Mutua, 2016). In Iraq, groundwater resources are gaining interest as an alternative source of water supply due to the prevalence of serious water quality issues. According to Alanbari et al. (2015), this issue will become more severe in the coming years due to a projected drop in the national water supply: expected to be $17.61 \mathrm{BCM}$ (billion cubic meters) in 2025 (whereas currently, demand is roughly approximate to be among $66.8 \mathrm{BCM}$ to $77 \mathrm{BCM}$ ). Alanbari et al. (2015) state that the discharges of the Tigris and Euphrates, the main rivers in Iraq, will continue to decrease with time, and both may be entirely dry by 2040 . Therefore, there is a real need to use groundwater as an alternative source of water supply. Many countries worldwide have used groundwater as an alternative source for water supply for various reasons, primarily a lack of suitable surface water. For instance, groundwater has been extracted in Europe since at least 1900 for public water supply, industrial use and irrigation (Zektser and Everett, 2004). The total demand for these three uses increased from $40 \mathrm{Km}^{3} / y e a r$ in 1900 to 720 $\mathrm{Km}^{3} /$ year in 2000, with demand more than doubling since 1970, (Zektser and Everett, 2004).

The availability of groundwater depends on the topography, surface drainage, geology, slope and land cover. The main factors that influence the water table's elevation determination are the slope and the topographic elevation. Similarly, the drainage pattern has a significant effect as it determines the precipitation rate, which may infiltrate into the ground (Nelly and Mutua, 2016). Rainfall has a vital role in controlling the amount and distribution of groundwater and the permeability of the ground surface. At the sub-surface level, infiltration and retention of the groundwater are heavily influenced by the permeability of the surrounding rock and soil type.

In Iraq, groundwater is becoming essential for potable water supply and irrigation use. Groundwater is also being used to help to maintain the base flow of rivers. The quality of groundwater can be high in many locations due to natural filtration. Groundwater is often colourless, transparent and free from microbial contamination, thus requiring minimal treatment (Singha et al., 2015). Contamination of groundwater results from natural or anthropogenic causes, and it is crucial to highlight that when groundwater is polluted, the water quality may not easily recover when sources of pollutants are stopped.

In some cases, groundwater pollution has been observed in several wells due to the absence of proper sewerage infrastructure (Iraq UN, 2013). Nowadays, pollutant threats have increased due to the number of soluble chemicals resulting from urbanisation, modern agricultural practices and industrial activities. The groundwater properties can be easily affected by the atmosphere, soil, water-rock reactions and external pollutant sources. Previous studies in developing countries have shown that a high percentage of disease is directly related to the low quality of drinking water (Singha et al., 2017), this reveals one of the main motivations of this work.

The present study uses the GIS software ArcGIS 10.5 (ESRI, 2015) to analyse groundwater quality and develop a spatial mapping of the associated data. ArcGIS has been used in other developing countries as a powerful tool for water resourcing and management (Singha et al., 2015). The developed maps are intended to aid decision making on groundwater management at a local, regional and national level. The study focuses on the central Iraqi region of 
Babylon Province, a crucial agricultural area for the country, which hosts several population centres. The investigation identifies the groundwater's chemical and microbiological properties and then assesses that water's suitability for various purposes such as drinking and irrigation using different indices. The selected indices used for evaluation of water quality are based on the local government authorities' recommendations. Additionally, the water areas are classified using GIS technology to obtain coloured maps for the water quality indices, enabling proposal of solutions to treat wastewater efficiently and identification of alternative water consumption sources in the future.

\section{Study area}

Babylon (known locally as Babil) Province is situated in central Iraq (the mid-Euphrates Region), approximately $100 \mathrm{~km}$ south of Baghdad. The longitudes and the latitudes of the province are located between $\left(44^{\circ} 2^{\prime} 42.245^{\prime \prime} \mathrm{E}-\right.$ $\left.45^{\circ} 2^{\prime} 2.964^{\prime \prime} \mathrm{E}\right)$ and $\left(32^{\circ} 25^{\prime} 55.287^{\prime} \mathrm{N}-33^{\circ} 7^{\prime} 34.229^{\prime \prime} \mathrm{N}\right)$, respectively. The province covers an area of $5119 \mathrm{~km}^{2}$. The Euphrates River flows for about $52 \mathrm{~km}$ through the study area, $34 \mathrm{~km}$ being upstream of the Hindyia barrage which controls the flow into downstream watercourses. Meanwhile, the Tigris River flows for about $112 \mathrm{~km}$ through the area, $20 \mathrm{~km}$ of this distance is located east of Babylon city. Not far from the world heritage site of Babylon's ancient city, Al-Hilla is the largest urban centre in the region and is bounded by a group of urban centres (Figure 1). The population of Babylon province was estimated to be 1728000 in 2015. In line with the rest of Iraq, the province is growing with an estimated growth rate of 2.7 (Iraq National Population Commission, 2012). One of the main economic activities for the province is agriculture, and the province is a key national resource in this sector. The regional economy's growth faces many challenges, most notably the continuing occurrence of droughts (IAU, 2010).

In the current study, various locations were selected to evaluate the groundwater quality across the province and a defined number of wells were selected for investigation. The study area comprises $4.4 \%$ of the Mesopotamia plain, covering about $116,000 \mathrm{~km}^{2}$ (Yacoub, 2011). The general topography of this area is characterised by its insignificant gradient from northwest to the southeast. The highest point is $\sim 62$ meters above sea level and is located in the northern part, while the lowest point is $\sim 21$ meters above sea level located in the southern part (Al-Madhlom et al., 2016). In general, the soil in this area has the nature of alluvial, fluvial silty clayey loam consistent with the soil of the whole of the Mesopotamia Plain, all derived from the fluvial depositions of the Euphrates and Tigris Rivers (Yacoub, 2011). 


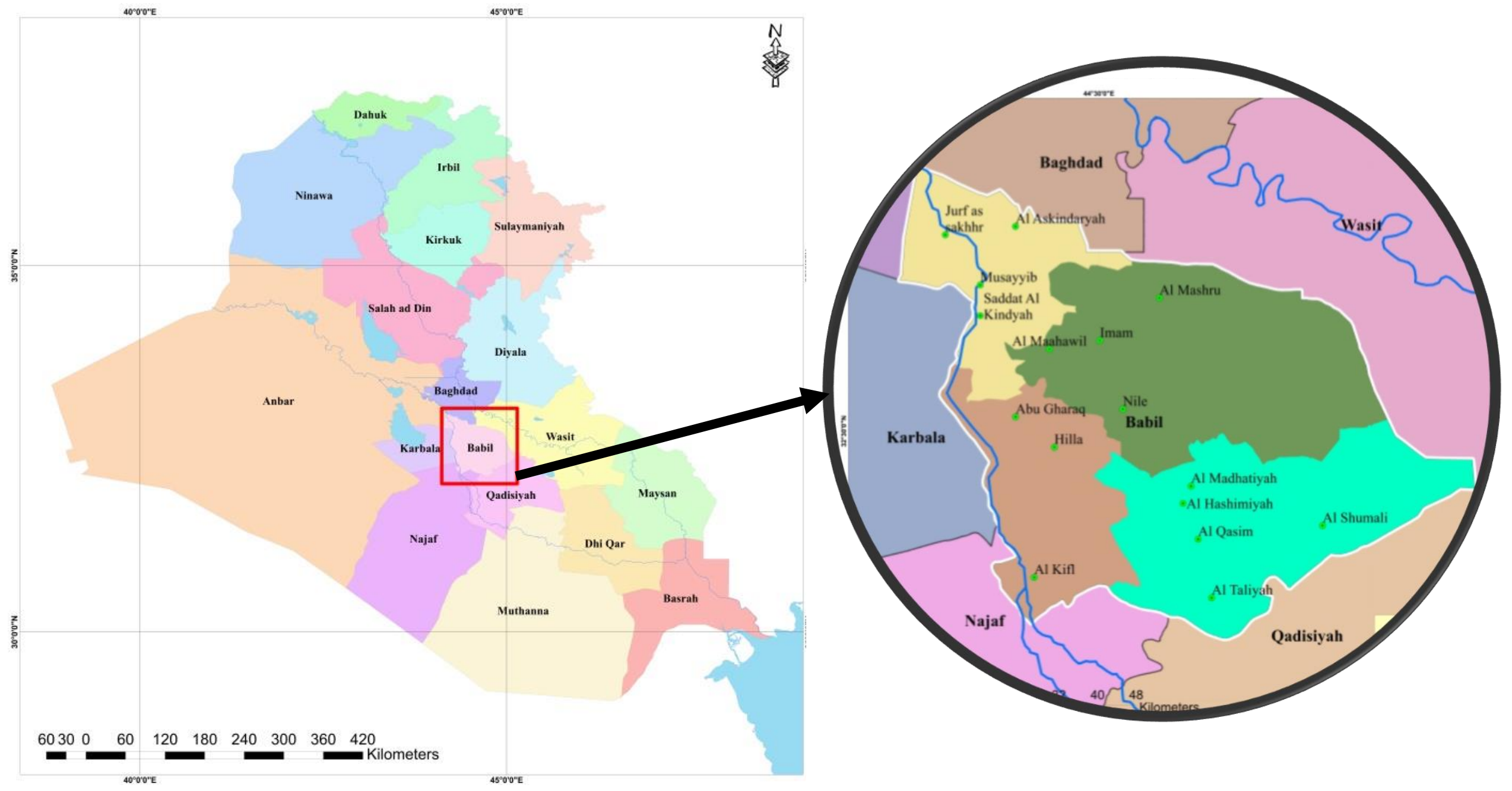

Fig 1. Location of the Study Area 
It is essential to highlight that investigating climate change is critical in studies related to shallow groundwater. Different climate elements play a key role in the rainfall rate and humidity that affect the soil's water content. Climate change features such as temperature rise, low rainfall, and dust storm generation significantly affect groundwater quality. The chosen area's climate is characterised by high temperature in summer and a short cold winter period. From November to April, the period is considered the wet season because $90 \%$ of the annual rainfall can occur with typical annual precipitation of $175 \mathrm{~mm}$. The annual evaporation rate may reach $2900 \mathrm{~mm} / \mathrm{year}$ in the Mesopotamia Plain (Yacoub, 2011). The study area's continental climate (desert climate) increases salts' concentration in the water (Madhloom and Al-Ansari, 2018). The study area's location is influenced by the regional tectonic actions that have formed the sedimentary plain's concave fold. Formation of the plane has continued with successive river sediment deposition over the millennia. The sediments in the study area consist of quaternary sediments from the Pliocene to Miocene age. The sediments are characterised by flood plains accumulating in thin layers. Meanwhile, the groundwater movement directions are influenced by several factors, including the topographic setting, precipitation, soil permeability, evapotranspiration, and recharge condition (Buday and Jassim, 167 1980).

This study is the first of its kind to consider this critical region of Iraq as a whole. Since the agricultural sector is pivotal to the regional economy, water shortage and water quality have a significant impact on both the economy and the population and in turn this can extend to the national level. Therefore, finding alternative means to irrigate crops and provide potable water is needed to mitigate the ongoing issue of water scarcity. The flow chart in Figure 2 outlines the adopted methodology in this study.

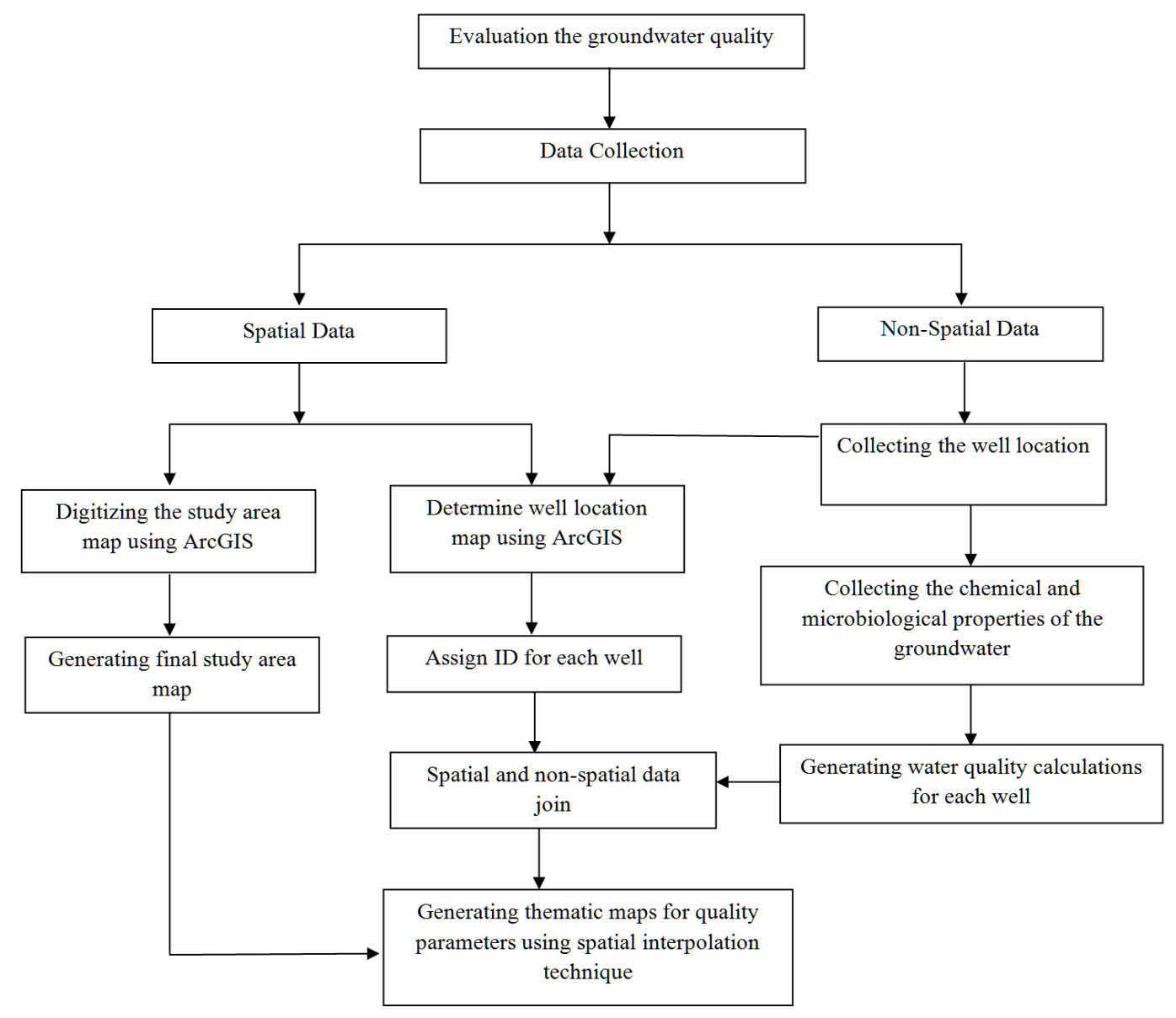


176 Sampling and Analysis

177 The groundwater sampled during the pre-monsoon season of 2015 from forty-nine selected wells distributed across

178 the province was evaluated. The data domain selection was in line with the approach adopted by previous

179 researchers such as Singha and Pasupuleti (2020) and Alam et al. (2020). The well parameters (e.g. well locations,

180 depths, drilling diameter and drilling purpose) are collected from the Water Resources Ministry in Iraq (Table 1). A

181 spatial variation of the study area's groundwater quality was carried using spatial analysis via ArcGIS. The spatial

182 distribution of the 49 wells is shown in Figure (3). The Water Resources Ministry in Iraq undertook the laboratory

183 testing of the chemical and microbiological properties. The collection, preservation and chemical analysis was

184 conducted following the American Public Health Association guidelines (APHA, 1998), see Table 2 for the 185 parameter test results.

186

Table 1 Sampling data for the selected well.

\begin{tabular}{|c|c|c|c|c|c|c|}
\hline Well number & Longitude & Latitude & Elevation & Purpose of drilling & Well depth (m) & Drilling diameter (Inch) \\
\hline w1 & 442039 & 322757 & 15 & Private benefit & 6 & 6 \\
\hline w2 & 442505 & 323202 & 19 & Public benefit & 30 & 5 \\
\hline w3 & 442449 & 323220 & 21 & Public benefit & 12 & 10 \\
\hline w4 & 442218 & 321232 & 15 & Public benefit & 6 & 16 \\
\hline w5 & 442541.0 & $\begin{array}{lll}32 & 15 & 01\end{array}$ & 12 & Public benefit & 6 & 16 \\
\hline w6 & $4424 \quad 46.3$ & $\begin{array}{lll}32 & 26 & 37.4\end{array}$ & 16 & Public benefit & - & - \\
\hline w7 & 442402.6 & 322300 & 14 & Public benefit & 12 & 12 \\
\hline w8 & $44 \quad 4834$ & $\begin{array}{lll}32 & 26 & 19\end{array}$ & 18.4 & Public benefit & 12 & 15 \\
\hline w9 & $\begin{array}{lll}45 & 01 & 18\end{array}$ & $32 \quad 2031$ & 7 & Public benefit & 12 & 15 \\
\hline w10 & 442652 & $\begin{array}{lll}32 & 13 & 10\end{array}$ & 14 & Public benefit & 12 & 10 \\
\hline w11 & $44 \quad 44 \quad 45$ & $\begin{array}{lll}33 & 08 & 11\end{array}$ & 11 & Public benefit & 12 & 15 \\
\hline w12 & $44 \quad 4138$ & $32 \quad 14 \quad 46$ & 17 & Public benefit & 12 & 15 \\
\hline w13 & 443644 & $32 \quad 1138$ & 11 & Public benefit & 12 & 15 \\
\hline w14 & 443922 & $32 \quad 12 \quad 44$ & 11 & Public benefit & 12 & 15 \\
\hline w15 & 443428 & $\begin{array}{lll}32 & 36 & 04\end{array}$ & 13 & Public benefit & 12 & 15 \\
\hline w16 & $4425 \quad 47$ & $32 \quad 40 \quad 23$ & & Public benefit & 12 & 15 \\
\hline w17 & $44 \quad 32 \quad 22$ & $32 \quad 32 \quad 41$ & 10 & Public benefit & $?$ & 15 \\
\hline w18 & $\begin{array}{lll}44 & 42 & 12\end{array}$ & $\begin{array}{lll}32 & 33 & 42\end{array}$ & 5 & Public benefit & 12 & 15 \\
\hline w19 & $4423 \quad 47$ & $\begin{array}{lll}32 & 38 & 41\end{array}$ & 14 & Public benefit & 12 & 15 \\
\hline w20 & $\begin{array}{lll}44 & 23 & 19\end{array}$ & $\begin{array}{lll}32 & 38 & 27\end{array}$ & 13 & Public benefit & 12 & 15 \\
\hline w21 & 442506 & $32 \quad 2704$ & 15 & Public benefit & - & - \\
\hline w22 & 443549 & $\begin{array}{lll}32 & 14 & 14\end{array}$ & 17 & Public benefit & 12 & 15 \\
\hline w23 & 442920 & $\begin{array}{lll}32 & 14 & 34\end{array}$ & 11 & Public benefit & 12 & 15 \\
\hline w24 & $44 \quad 27 \quad 19$ & $\begin{array}{lll}32 & 17 & 24\end{array}$ & 15 & Public benefit & - & - \\
\hline w25 & 442148 & $32 \quad 22 \quad 44$ & 25 & Public benefit & 12 & 15 \\
\hline w26 & 442305 & $\begin{array}{lll}32 & 20 & 30\end{array}$ & 16 & Public benefit & 12 & 15 \\
\hline w27 & $44 \quad 18 \quad 34$ & $\begin{array}{lll}32 & 43 & 05\end{array}$ & 27 & Public benefit & 12 & 15 \\
\hline
\end{tabular}




\begin{tabular}{|c|c|c|c|c|c|c|}
\hline w28 & $\begin{array}{lll}44 \quad 45 \quad 42\end{array}$ & 322429 & 21 & Public benefit & 12 & 15 \\
\hline w29 & 442223 & $\begin{array}{lll}32 & 21 & 43\end{array}$ & 14 & Public benefit & 12 & 15 \\
\hline w30 & 442147 & $32 \quad 2211$ & 12 & Public benefit & - & - \\
\hline w31 & $44 \quad 2807$ & $32 \quad 3738$ & 14 & Public benefit & 12 & 15 \\
\hline w32 & 442749 & $32 \quad 37 \quad 16$ & 13 & Public benefit & 12 & 15 \\
\hline w33 & 442912 & $\begin{array}{lll}32 & 35 & 15\end{array}$ & 20 & Public benefit & 12 & 15 \\
\hline w34 & $4442 \quad 26$ & $\begin{array}{lll}32 & 31 & 02\end{array}$ & 13 & Public benefit & 12 & 15 \\
\hline w35 & 443742 & $32 \quad 34 \quad 15$ & 11 & Public benefit & 12 & 15 \\
\hline w36 & $44 \quad 22 \quad 54.1$ & $\begin{array}{lll}32 & 18 & 08.5\end{array}$ & 21 & Public benefit & 12 & 15 \\
\hline w37 & 443700 & 323746 & 14 & Public benefit & 12 & 15 \\
\hline w38 & $4434 \quad 17$ & $\begin{array}{lll}32 & 39 & 24\end{array}$ & 17 & Public benefit & 15 & 15 \\
\hline w39 & $44 \quad 57 \quad 07$ & $32 \quad 30 \quad 23$ & 15 & Public benefit & 12 & 15 \\
\hline w40 & 445924 & $\begin{array}{lll}32 & 31 & 59\end{array}$ & 2 & Public benefit & 12 & 15 \\
\hline w41 & $44 \quad 1703$ & $\begin{array}{lll}32 & 43 & 27\end{array}$ & 20 & Public benefit & 12 & 15 \\
\hline w42 & 445750 & $32 \quad 2633$ & 13 & Public benefit & 12 & 15 \\
\hline w43 & 445659 & $\begin{array}{lll}32 & 29 & 15\end{array}$ & 13 & Public benefit & - & - \\
\hline w44 & 442022 & 323155 & 11 & Public benefit & 12 & 15 \\
\hline w45 & 441926 & 323150 & 16 & Public benefit & 12 & 15 \\
\hline w46 & 441855 & $32 \quad 2955$ & 15 & Public benefit & - & - \\
\hline w47 & $44 \quad 19 \quad 47.4$ & $\begin{array}{lll}32 & 32 & 23.8\end{array}$ & 14 & Public benefit & 12 & 15 \\
\hline w48 & $\begin{array}{lll}44 & 19 & 47.4\end{array}$ & $\begin{array}{lll}32 & 32 & 23.8\end{array}$ & 20 & Public benefit & 12 & 15 \\
\hline w49 & 442252 & $32 \quad 2054$ & 11 & Public benefit & 10 & 15 \\
\hline
\end{tabular}

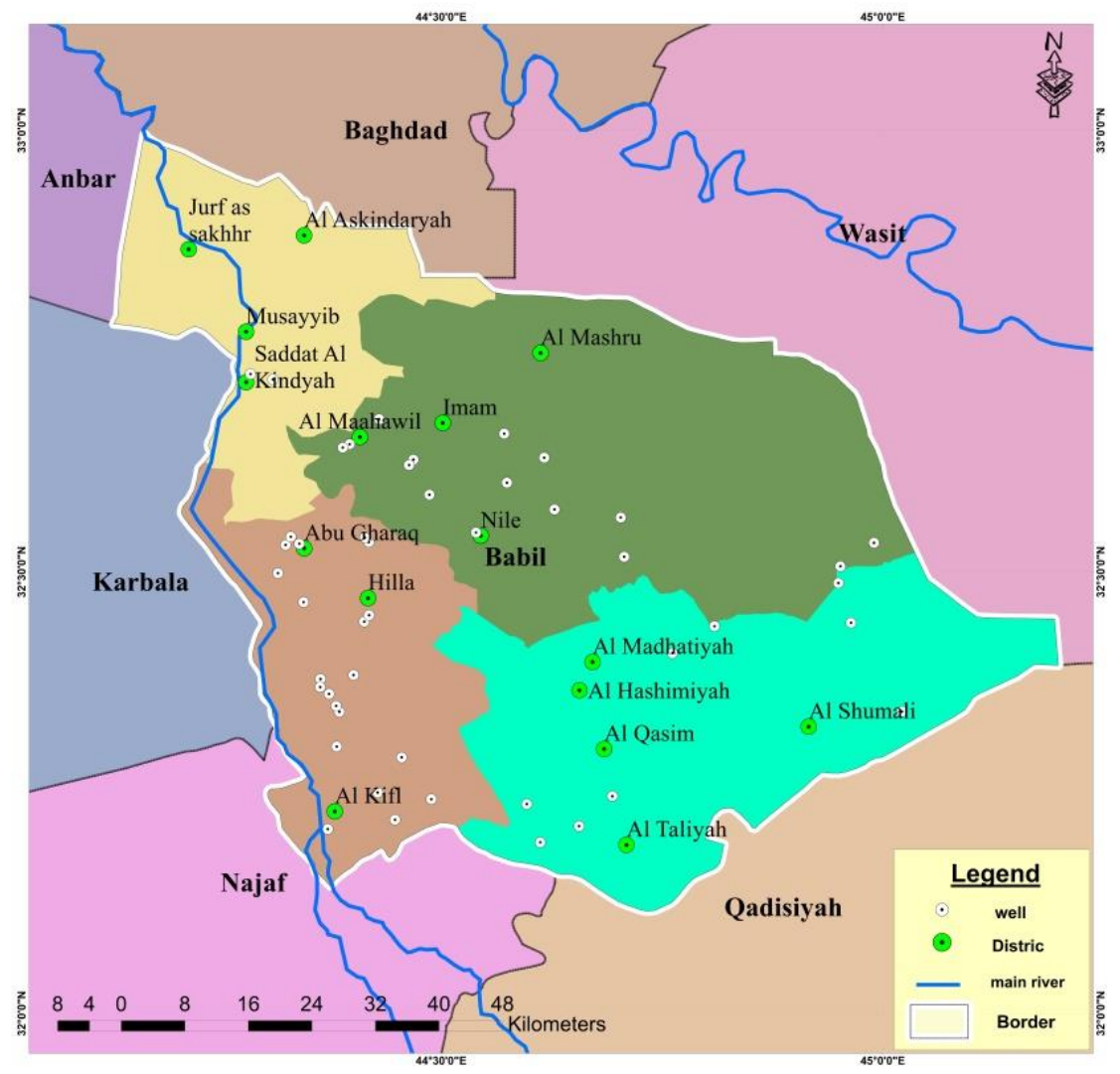

Fig. 3 Location of the sampling sites 
Table 2 Chemical characteristics for the collected samples

\begin{tabular}{|c|c|c|c|c|c|c|c|c|c|c|c|c|}
\hline $\begin{array}{c}\text { Well } \\
\text { Numb } \\
\text { er }\end{array}$ & $\mathbf{P H}$ & $\begin{array}{c}\mathrm{EC}(\mu \mathrm{s} \\
/ \mathrm{cm})\end{array}$ & $\begin{array}{c}\text { TDS } \\
\text { (ppm, } \\
\text { parts per } \\
\text { million) }\end{array}$ & $\begin{array}{c}\mathrm{Na}^{+} \\
(\mathrm{meq} / \mathrm{l})\end{array}$ & $\begin{array}{c}\mathrm{Mg}^{+2} \\
(\mathrm{meq} / \mathrm{l})\end{array}$ & $\begin{array}{c}\mathrm{Ca}^{+2} \\
(\mathrm{meq} / \mathrm{l})\end{array}$ & $\begin{array}{c}\mathrm{Cl}^{-} \\
(\mathrm{meq} / \mathrm{l})\end{array}$ & $\begin{array}{c}\mathbf{K}^{+} \\
(\mathrm{meq} / \mathrm{l})\end{array}$ & $\begin{array}{l}\mathrm{SO}_{4}^{-2} \\
(\mathrm{meq} / \mathrm{l})\end{array}$ & $\begin{array}{l}\mathrm{HCO}_{3}^{-} \\
(\mathrm{meq} / \mathrm{l})\end{array}$ & $\begin{array}{c}\mathrm{NO}_{3}^{-} \\
(\mathrm{meq} / \mathrm{l})\end{array}$ & $\begin{array}{l}\mathrm{CO}_{3}{ }^{-2} \\
(\mathrm{meq} / \mathrm{l})\end{array}$ \\
\hline w1 & 7.41 & 8170 & 5547 & 34.844 & 19.917 & 22.455 & 29.977 & 0.2637 & 36.2544 & 9.0036 & 0.1288 & 0 \\
\hline w2 & 7.38 & 1733 & 1250 & 8.352 & 3.5389 & 4.2914 & 9.024 & 0.0512 & 5.616 & 1.5744 & 0.0483 & 0 \\
\hline w3 & 7.25 & 1082 & 1040 & 3.9585 & 5.9256 & 5.6387 & 3.0174 & 0.1536 & 8.9648 & 0.8364 & 0.0322 & 0 \\
\hline w4 & 7.15 & 3160 & 2409 & 16.313 & 8.6415 & 11.1776 & 15.002 & 0.0768 & 16.016 & 5.084 & 0.0966 & 0 \\
\hline w5 & 7.3 & 1128 & 930 & 5.655 & 4.2796 & 3.992 & 7.2474 & 0.0896 & 7.0096 & 2.4108 & 0.0322 & - \\
\hline w6 & 7.13 & 8140 & 5580 & 25.274 & 13.250 & 17.5149 & 22.447 & 3.0976 & 28.392 & 8.3804 & 0.0322 & - \\
\hline w7 & 7.12 & 3690 & 2590 & 15.225 & 9.4645 & 10.7285 & 14.946 & 0.1024 & 12.48 & 7.462 & 0.0483 & 0 \\
\hline w8 & 7.31 & 2530 & 1830 & 7.9605 & 8.1477 & 7.2854 & 7.755 & 0.3584 & 13.3744 & 2.3944 & 0.06118 & - \\
\hline w9 & 7.14 & 2030 & 1418 & 4.089 & 5.1026 & 8.982 & 4.2018 & 0.1562 & 12.7088 & 1.5908 & 0.0322 & 0 \\
\hline w10 & 7.71 & 1238 & 890 & 3.828 & 5.5141 & 5.4391 & 5.1042 & 0.128 & 7.8832 & 0.8036 & 0.1288 & - \\
\hline w11 & 7.5 & 2060 & 1449 & 7.0035 & 6.584 & 6.487 & 10.490 & 0.1587 & 7.0304 & 2.3944 & - & 0.066 \\
\hline w12 & 7.19 & 1077 & 800 & 6.438 & 2.3044 & 2.6447 & 5.358 & 0.0154 & 4.784 & 1.1152 & 0.0483 & - \\
\hline w13 & 7.14 & 2040 & 1418 & 4.089 & 5.1026 & 8.982 & 4.2018 & 0.1536 & 12.7088 & 1.5908 & 0.0322 & - \\
\hline w14 & 7.7 & 910 & 800 & 6.4815 & 2.3867 & 2.6946 & 5.3298 & 0.0384 & 4.8048 & 1.1316 & 0.0322 & - \\
\hline w15 & 7.5 & 1949 & 1450 & 10.745 & 1.7283 & 1.8463 & 5.076 & 0.1766 & 6.4896 & 3.1816 & 0.05635 & - \\
\hline w16 & 7.16 & 3690 & 2900 & 17.879 & 10.618 & 13.1237 & 15.313 & 2.0224 & 20.5712 & 7.38 & 0.11592 & - \\
\hline w17 & 7.31 & 3030 & 2188 & 14.529 & 7.7362 & 9.2315 & 10.716 & 0.256 & 14.1648 & 6.0516 & 0.0322 & - \\
\hline w18 & 7.31 & 2460 & 1919 & 5.829 & 6.8309 & 6.2375 & 6.768 & 0.2816 & 11.336 & 1.066 & - & 0.099 \\
\hline w19 & 7.31 & 1193 & 900 & 5.6115 & 4.115 & 3.9421 & 7.2474 & 0.0794 & 5.2208 & 1.0168 & - & 0.066 \\
\hline w20 & 7.1 & 8840 & 6190 & 32.712 & 18.518 & 29.441 & 29.920 & 0.4352 & 38.6464 & 12.3984 & 0.1127 & - \\
\hline w21 & 7.22 & 3640 & 2592 & 9.222 & 11.604 & 12.6746 & 15.228 & 0.256 & 16.4528 & 3.2964 & 0.10465 & - \\
\hline w22 & 7.12 & 937 & 800 & 6.4815 & 2.3867 & 2.6946 & 5.3298 & 0.0384 & 4.8048 & 1.1316 & 0.0322 & 0 \\
\hline w23 & 7.2 & 1406 & 1095 & 3.6975 & 5.4318 & 3.493 & 5.3298 & 0.1152 & 7.8 & 1.6072 & 0.03703 & 0 \\
\hline w24 & 7.12 & 1045 & 772 & 2.2185 & 2.0575 & 2.0958 & 2.6226 & 0.0230 & 1.8096 & 2.05 & 0.0644 & 0 \\
\hline w25 & 7.71 & 16090 & 13200 & 38.672 & 34.648 & 38.9719 & 47.376 & 0.1792 & 47.8816 & 16.9412 & 0.2576 & - \\
\hline w26 & 7.2 & 1631 & 1300 & 11.267 & 3.4566 & 5.0898 & 10.096 & 0.256 & 8.736 & 1.2792 & 0.00161 & 0 \\
\hline w27 & 7.4 & 3000 & 2221 & 5.6985 & 7.5716 & 6.5369 & 7.05 & 0.3584 & 11.627 & 1.0824 & 0.05635 & 0 \\
\hline w28 & 7.2 & 2420 & 1955 & 10.005 & 4.1973 & 8.0838 & 6.7116 & 0.0922 & 11.482 & 4.0016 & 0.0644 & - \\
\hline w29 & 7.6 & 973 & 840 & 6.5685 & 2.3044 & 2.7944 & 5.3862 & 0.0512 & 4.8464 & 1.1152 & 0.01771 & 0 \\
\hline w30 & 7.13 & 24500 & 17900 & 91.35 & 32.591 & 45.0098 & 93.201 & 2.0992 & 51.9168 & 20.5328 & 0.15295 & 0 \\
\hline w31 & 7.91 & 4990 & 3410 & 29.624 & 9.7937 & 9.4311 & 17.597 & 0.3072 & 24.9184 & 6.724 & 0.1449 & 0 \\
\hline w32 & 7.13 & 1340 & 1080 & 6.438 & 2.6336 & 2.9441 & 5.2452 & 0.0666 & 5.1792 & 1.0824 & 0.0322 & 0 \\
\hline w33 & 7.7 & 916 & 805 & 6.4815 & 2.3867 & 1.6966 & 5.3298 & 0.0384 & 4.8048 & 1.1316 & 0.0322 & 0 \\
\hline w34 & 7.31 & 3020 & 2188 & 14.529 & 7.7362 & 9.2315 & 10.716 & 0.256 & 14.1648 & 6.0516 & 0.0322 & 0 \\
\hline w35 & 7.2 & 1327 & 1260 & 5.7855 & 7.1601 & 6.4371 & 6.8244 & 0.384 & 11.4608 & 1.1152 & 0.0322 & 0 \\
\hline w36 & 7.2 & 1375 & 1260 & 7.134 & 6.584 & 5.8383 & 8.7702 & 0.2304 & 9.5472 & 1.3776 & 0.1449 & 0 \\
\hline w37 & 7.15 & 3440 & 2400 & 16.095 & 8.5592 & 11.1277 & 15.002 & 0.0768 & 16.0784 & 5.0676 & 0.0966 & 0 \\
\hline w38 & 7.15 & 2220 & 1727 & 10.919 & 1.5637 & 1.7964 & 4.4556 & 0.1818 & 6.4064 & 3.2636 & 0.0644 & 0 \\
\hline w39 & 7.15 & 2850 & 2000 & 18.662 & 2.9628 & 3.5429 & 10.208 & 0.3098 & 10.608 & 4.428 & 0.0805 & 0 \\
\hline w40 & 7.1 & 1852 & 1582 & 7.917 & 7.6539 & 7.5349 & 12.408 & 0.1792 & 8.3616 & 2.4272 & 0.0322 & 0 \\
\hline w41 & 7.23 & 3540 & 2950 & 18.27 & 9.9583 & 13.5229 & 16.638 & 4.352 & 22.1936 & 4.0672 & 0.05635 & 0 \\
\hline w42 & 7.5 & 6580 & 4724 & 25.578 & 11.769 & 17.6147 & 18.02 & 1.1264 & 31.1376 & 6.7568 & 0.0966 & 0 \\
\hline
\end{tabular}




\begin{tabular}{|c|c|c|c|c|c|c|c|c|c|c|c|c|}
\hline w43 & 7.41 & 21300 & 14900 & 60.422 & 31.192 & 46.1076 & 82.682 & 1.6896 & 29.536 & 20.1064 & 0.0966 & $\overline{0}$ \\
\hline w44 & 7.41 & 7440 & 5213 & 27.318 & 15.226 & 18.8622 & 26.508 & 0.0307 & 38.1888 & 8.4952 & 0.0322 & 0 \\
\hline w45 & 7.25 & 4940 & 3674 & 23.055 & 11.275 & 14.2215 & 18.274 & 2.304 & 24.4816 & 7.7572 & 0.0322 & 0 \\
\hline w46 & 7.32 & 4980 & 3910 & 23.49 & 13.168 & 16.7165 & 20.360 & 3.0208 & 27.56 & 8.364 & 0.0322 & 0 \\
\hline w47 & 7.17 & 13400 & 21600 & 101.4 & 22.056 & 54.9898 & 107.13 & 5.0944 & 59.904 & 33.0132 & 0.1288 & 0 \\
\hline w48 & 7.13 & 21500 & 17450 & 91.35 & 32.591 & 45.0098 & 93.201 & 2.0992 & 51.9168 & 20.5328 & 0.1449 & 0 \\
\hline w49 & 7.5 & 1922 & 1800 & 14.964 & 6.7486 & 6.5369 & 12.944 & 0.3328 & 13.936 & 1.476 & 0.0322 & 0 \\
\hline
\end{tabular}

Water quality index (WQI)

The WQI is an arithmetical tool used to transform large quantities of water quality data into a single cumulatively derived number and can be utilised to assess and manage groundwater quality (Reyes-Toscano et al., 2020). The WQI was primarily proposed by Brown et al. (1972) then modified by Backman et al. (1998). The primary outcome of calculating the water quality indices (WQIs) is assessing freshwater suitability for different uses. WQI is mainly based on comparing the measured water quality parameters obtained from the field to regulatory standards (Husain, 1998). However, the WQI cannot be used to substitute the required thorough analysis needed for environmental monitoring and modelling. The advantages of these indices are their ability to represent various variable measurements in a single number. Further, the indices can combine various measurements with various measurement units in a single unit, thus simplifying the results (Zandbergen and Hall, 1998). There are many approaches for quantifying the WQI, such as the formulae, which could be either independent or dependent on water 202 quality standards (Khan et al., 2003).

The evaluation of drinking water quality usually adopts the WQI approach as a reliable measurement and groundwater quality assessment. According to the World Health Organization (WHO) report published in 2004, the WQI illustrates the combined qualitative and measured parameters of the drinking water quality in relation to the WHO recommendations (World Health Organization, 2004). As a result, the WQI can be considered a valuable tool in assessing groundwater quality used for drinking. As this study is conducted in Iraq, it was necessary to review the Iraqi provisions for drinking water and the qualitative parameters' standards (Madhloom and Al-Ansari, 2018). The standard values of most of the parameters have maximum and minimum numbers which are very close to the WHO standards; hence the WHO standards are applied in this work.

Herein the WQI is obtained following the Weighted Arithmetic Index Method (Cude, 2001). The method 212 multiplies the water quality components by a weighting factor then sums the results using the simple arithmetic 213 mean. To assess the quality of groundwater, the quality rating scale (Qi) for each parameter is firstly estimated using 214 Equation 1:

$215 Q i=\left[\frac{\left(V_{\text {actual }}-V_{\text {ideal }}\right)}{\left(V_{\text {standard }}-V_{\text {ideal }}\right)} * 100\right]$

216 Where, $\mathrm{Q} i=$ the quality rating of the $\mathrm{i}^{\text {th }}$ parameter for the total of $\mathrm{n}$ water quality parameters,

$217 \mathrm{~V}_{\text {actual }}=$ the actual value of the parameter which could be achieved from the laboratory test,

$218 \mathrm{~V}_{\text {ideal }}=$ the ideal value of the same parameter which is gained from a standard table,

$219 \mathrm{~V}_{\text {ideal }}$ for $\mathrm{pH}=7$ but for other parameters it is zero.

$220 \quad \mathrm{~V}_{\text {standard }}=$ the recommended value of the parameter and is presented in Table 3. 
Table 3 Water quality parameter based on WHO standards

\begin{tabular}{cc}
\hline Parameter & Standards \\
\hline $\mathrm{pH}$ & 8.5 \\
$\mathrm{Mg}$ & 150 \\
$\mathrm{Ca}$ & 200 \\
$\mathrm{Cl}$ & 250 \\
$\mathrm{SO} 4$ & 400 \\
$\mathrm{NO} 3$ & 50 \\
$\mathrm{EC}$ & 1000 \\
$\mathrm{TDS}$ & 500 \\
\hline
\end{tabular}

224

To determine WQI, the relative weight (Wi) is estimated by a value inversely proportional to the recommended standard $(\mathrm{Si})$ for the corresponding parameter using Equation 2;

$W i=\frac{1}{S i}$

Where Wi $=$ Relative weight of nth parameter

$\mathrm{Si}=$ Standard permissible value of the nth parameter.

Then, the overall WQI is calculated by linear combining of the quality rating with the relative weight according to Equation 3;

$W Q I=\frac{\sum Q i W i}{\sum W i}$

For the current paper, the maximum ground WQI suitable for human consumption (for drinking purposes) would be considered a 100 score (Ministry of Environment, 1998). Based on the WQI values, the groundwater quality will be rated, as shown in Table 4.

Table 4 Water quality index levels adopted in this study based on WHO standards

\begin{tabular}{cc}
\hline Water quality index & Description \\
\hline $0-25$ & Excellent \\
$26-50$ & good \\
$51-75$ & poor \\
$76-100$ & very poor \\
$>100$ & Unfit for drink \\
\hline
\end{tabular}

\section{Irrigation Water Quality Index (IWQI)}

238 Many studies have used the irrigation water quality index (IWQI) that was essentially developed by Meireles et al. 239 (2010). More recently, Abbasnia et al. (2018) used the IWQI to evaluate the water quality when used for irrigation 240 in Iran. There are slight differences between the IWQI method and the WQI based method conducted by the WHO.

241 In order to find the relative weight, the predictable values of each parameter need to be applied. These estimated 242 values have originated based on the irrigation water quality data obtained by the University of California Committee 243 of Consultants (UCCC) and Ayers and Westcot (1994). Using the IWQI model, the dominant parameters must be 244 identified as they play a significant part in assessing irrigation water quality. The dominant parameters include EC, $245 \mathrm{Na}^{+}, \mathrm{Cl}^{-}, \mathrm{HCO}_{3}^{-}$and SAR. SAR (Sodium Adsorption Ratio) is obtained using Equation 4: 
$246 S A R=\frac{N a^{+}}{\sqrt{\frac{C a^{+2}+M g^{+2}}{2}}}$

After obtaining the required parameters, the accumulation weights (wi) values proposed by Meireles et al., 2010 are then applied. It is worth highlighting that the total value for the five parameters is equal to one (see Table 5) according to Ayers and Westcot, (1994) recommendations.

Table 5 IWQI Weights (Meireles et al., 2010)

\begin{tabular}{cc}
\hline Parameter & Weight (wi) \\
\hline $\mathrm{EC}$ & 0.211 \\
$\mathrm{Na}^{+}$ & 0.204 \\
$\mathrm{HCO}^{-}$ & 0.202 \\
$\mathrm{Cl}^{-}$ & 0.194 \\
$\mathrm{SAR}$ & 0.189 \\
Total & $\mathbf{1 . 0}$ \\
\hline
\end{tabular}

The water quality measurement parameter (Qi) value and the accumulation witness (Wi) are obtained using each individual parameter value. The criteria suggested by Ayers and Westcot (1994) is adopted during the calculations (see Table 6).

Low Qi values indicate that the groundwater quality is insufficient; meanwhile, high Qi values demonstrate that the groundwater quality is good. The Qi values are obtained using Equation 5:

$$
\mathrm{Q}_{\mathrm{i}}=\mathrm{q}_{\max }-\left(\frac{\left(\mathrm{x}_{\mathrm{ij}}-\mathrm{x}_{\mathrm{inf}}\right) * \mathrm{q}_{\mathrm{iamp}}}{\mathrm{x}_{\mathrm{amp}}}\right)
$$

Where,

qmax: the maximum Qi value for each class,

Xij: the observed value of each parameter,

Xinf: the lower limit value of the class to which the parameter belongs,

qimap: the class amplitude

Xamp: the class amplitude to which the parameter belongs.

In this case, the upper limit is treated as the highest value obtained from the water sample analyses and involves assessing Xamp for each parameter's last class. Finally, the Irrigation water quality index (IWQI) can be determined using Equation 6:

$I W Q I=\sum_{i=1}^{n} Q i * w i$

\section{Where;}

IWQI: non-dimensional and ranges (0 to 100$)$,

Qi: the quality measurement of a parameter,

$\mathrm{i}^{\text {th: }}$ a function of its concentration (0 to 100$)$.

wi: the normalised weight of the $\mathrm{i}^{\text {th }}$ parameter.

Table 6 Qi limiting values (Ayers and Westcot, 1994)

\begin{tabular}{cccccc}
\hline $\mathbf{N a}^{+}$ & $\mathbf{C l}^{-}$ & $\mathbf{H C O}^{-}$ & $\begin{array}{c}\mathbf{E C} \\
(\boldsymbol{\mu s} / \mathbf{c m})\end{array}$ & $\begin{array}{c}\text { SAR } \\
(\mathbf{m e q} /)^{\mathbf{0 . 5}}\end{array}$ & Qi \\
\cline { 1 - 2 }$(\mathbf{m e q} / \mathbf{l})$ & & $200 \leq \mathrm{EC}<750$ & $2 \leq \mathrm{SAR}<3$ & $85-100$ \\
$3 \leq \mathrm{Na}^{+}<3$ & $1 \leq \mathrm{Cl}^{-}<4$ & $1 \leq \mathrm{HCO}_{3}{ }^{-}<1.5$ & & $3 \leq \mathrm{SAR}<6$ & $60-85$
\end{tabular}




$$
\begin{array}{cccccc}
6 \leq \mathrm{Na}^{+}<9 & 7 \leq \mathrm{Cl}^{-}<10 & 4.5 \leq \mathrm{HCO}_{3}{ }^{-}<8.5 & 1500 \leq \mathrm{EC}<3000 & 6 \leq \mathrm{SAR}<12 & 35-60 \\
\mathrm{Na}^{+}<2 \text { or } & 1<\mathrm{Cl}^{-} \geq 10 & \mathrm{HCO}_{3}{ }^{-}<1 \text { or } & \mathrm{EC}<200 \text { or } & 2<\mathrm{SAR} \geq 12 & 0-35 \\
\mathrm{Na}^{+} \geq 9 & & \mathrm{HCO}_{3}{ }^{-} \geq 8.5 & \mathrm{EC} \geq 3000 &
\end{array}
$$

Table 7 Irrigation Water Quality Index Characteristics (Meireles et al., 2010)

IWQI is classified into five dimensionless parameter classes to determine the irrigation water class suitability (Meireles et al., 2010). As shown in Table 7, this classification was based on the suggested groundwater quality index. Furthermore, Bernardo et al. (1995) has defined the classes depending on their effect on vegetation, e.g. soil water infiltration reduction, salinity hazard, and toxicity.

\section{Table 7 Irigaion Water Quality Index Characteristies (Meireles et al., 2010)}

\begin{tabular}{lrc}
\hline Recommendation & Water use restrictions & IWQI \\
\hline $\begin{array}{l}\text { Plant } \\
\text { No toxicity risk }\end{array}$ & No restriction (NR) & $85-100$ \\
$\begin{array}{l}\text { Avoid salt-sensitive plants } \\
\text { Plants which have moderate tolerance to salts }\end{array}$ & Low restriction (LR) & $70-85$ \\
$-\quad$ Plants with moderate to high tolerance to salts & Moderate restriction (MR) & $55-70$ \\
$-\quad$ Except for water with low values of $\mathrm{Cl}^{-}, \mathrm{Na}^{+}$and $\mathrm{HCO}_{3}^{-}$ & High restriction (HR) & $40-55$ \\
$-\quad$ Plants with high salt tolerance, & & $0-40$ \\
$-\quad$ Except for waters with extremely low values of $\mathrm{Cl}^{-}, \mathrm{Na}^{+}$and $\mathrm{HCO}_{3}^{-}$ & Severe restriction (SR) \\
\hline
\end{tabular}

279

280

Several Indices have been used globally to evaluate water quality for irrigation (Raihan and Alam, 2008; Sarkar and Hassan, 2006; Talukder et al., 1998; Quddus, 1996; Todd, 1995; Raghunath, 1987). The mineral constituents in the water used for irrigation affect the soil and associated plant growth, therefore groundwater suitability would largely depend on its mineral constituents. One of the most harmful mineral constituents to plants is salt as it impacts their metabolic rate by limiting the water intake. Furthermore, salts can influence the structure, aeration and the soil's permeability, indirectly impacting the crops' growth. The water suitability for irrigation relies on various aspects regardless of the water properties itself, such as the soil drainage properties, soil type, climate of the area and plants' tolerance to salt (Michael, 1990).

Sodium concentration is another essential factor that needs to be considered in all the classification Indices for irrigation water as a result of sodium reactions with soil which can lead to a decrease in permeability (Todd, 1995). Similarly, Kelly's Ratio, Permeability Index (PI), Residual Sodium Carbonate (RSC), Soluble Sodium percentage (SSP), Sodium Adsorption Ratio (SAR) and the Electrical conductivity (EC) can be categorised as crucial indices in the determination of water irrigation suitability (Khan and Abbasi, 2013). Thus, SSP, RSC, PI, and KR were calculated in this investigation using Equation 7 to Equation 10:

$S S P=\frac{N a^{+} * 100}{\mathrm{Ca}^{+2}+M g^{+2}+N a^{+}}$

$R S C=\left(\mathrm{CO}_{3}{ }^{-2}+\mathrm{HCO}_{3}{ }^{-}\right)-\left(\mathrm{Ca}^{+2}+\mathrm{Mg}^{+2}\right)$

$P I=\frac{\mathrm{Na}^{+}+\sqrt{\mathrm{HCO}_{3}^{-}}}{\mathrm{Ca}^{+2}+\mathrm{Mg}^{+2}+\mathrm{Na}^{+}} * 100$

$K R=\frac{N a^{+}}{C a^{+2}+M g^{+2}}$

where the concentration of ions is expressed in meq/l. 
Eventually, using the GIS environment, the numerical, spatial distribution of the tested parameters was generated from analytical results and subsequently, the Inverse Distance weight technique (IDW) was implemented to generate the spatial distribution maps of water quality parameters. The IDW can be defined as a deterministic method used to conduct multivariate interpolation calculations with a known scattered set of points. The cell values can be allocated using a linear-weighted combination set of sample points. In this study, the IDW was selected as it

304 is the most suitable interpolating technique.

\section{Results and discussion}

306 ArcGIS has been used based upon the data of 49 wells across the region in order to generate the required database 307 for groundwater suitability for drinking and irrigation. These databases were then used to create maps of the spatial 308 distribution of all parameters which will be presented and discussed in the next sections of this paper. These maps provide a precise evaluation of groundwater quality and estimate the well's extraction potential with the lowest pollutant contents. It is important to emphasise that the IWQI was calculated using the EC, SAR, $\mathrm{Na}^{+}, \mathrm{Cl}^{-}$and $311 \mathrm{HCO}_{3}^{-}$parameters and the spatial distribution maps were created for each parameter and integrated via 312 ArcGIS/spatial analyst function according to Equation (5). This integration offers a map of the IWQI index obtained 313 using geostatistical analysis.

\section{Water Quality Index (WQI)}

315 Virtualising the groundwater quality by location using ArcGIS maps is very important for evaluating the usability of 316 water. The variations of physicochemical characteristics and the WQI of the groundwater in various places around 317 the study area will be presented. The groundwater quality shows variations from well to well, attributed to the 318 surface and subsurface features. Spatial interpolation of ArcGIS using the WQI parameter was utilised for plotting a 319 digital map to describe the suitability of water for human needs in the study area. These maps represent an efficient 320 tool for managing the water quality and minimising the negative impacts on the ambient environment (Figure 4).

The results show that around $78 \%$ of water samples are potentially suitable for drinking purposes; however, around $22 \%$ of the samples are not suitable for human use. As previously discussed, ongoing water shortages in Iraq mean that groundwater resources' demand will rise with time. Thus, more attention is required to avoid groundwater pollution as it can create severe consequences in the future. 


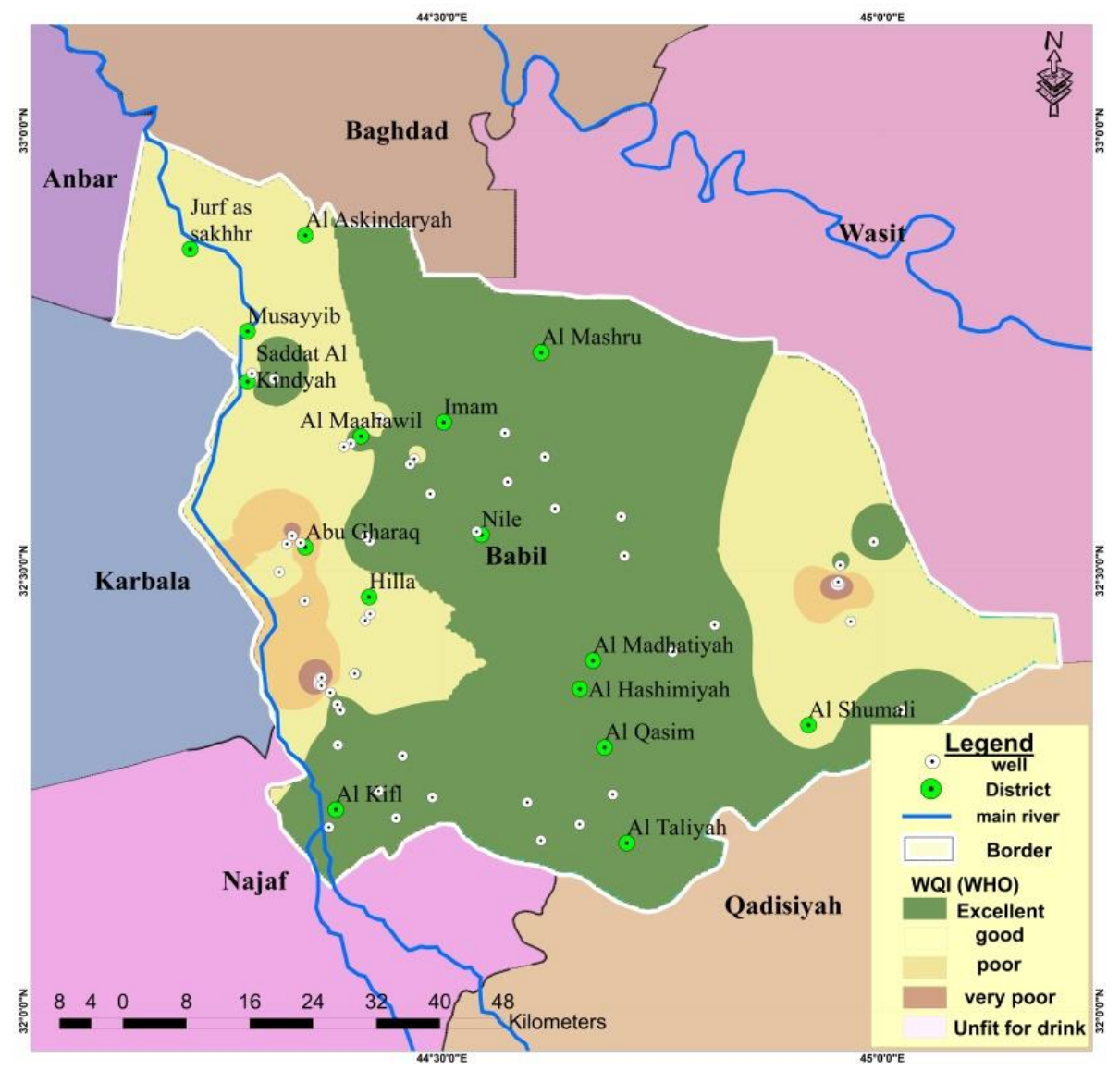

Fig. 4 WQI Spatial distribution map

\section{$327 \quad$ Irrigation Water Quality Index (IWQI)}

328 Many factors can alter groundwater quality such as the use of fertilisers, malfunction of underground drainage systems, mining activities, disposal of industrial wastes, continuous burning of municipal solid waste (MSW) and presence of landfills. The diversity of water quality in the focussed region is described as follows:

- As shown in Figure (5), the studied water samples' pH value ranged between 7.1 and 7.91. High pH values up to 8.5 in groundwater can be attributed to bicarbonate ions that form the groundwater's main alkaline component (Jerome and Pius, 2010). The variation of $\mathrm{pH}$ between low and high values affects plants' ability to absorb the soil's nutrients. Low $\mathrm{pH}$ increases the solubility of manganese and ammonium salts to concentrations that can be harmful to plants.

- The results showed that the bicarbonate ion $\left(\mathrm{HCO}_{3}^{-}\right)$concentration in the water samples ranged from 0.804 -33.013 meq/l, see Figure (6). Ayers and Westcot (1994) pointed out that bicarbonate's ideal concentration for irrigation purposes is less than $1.5 \mathrm{meq} / \mathrm{l}$. Therefore, all water samples are not appropriate for irrigation. 


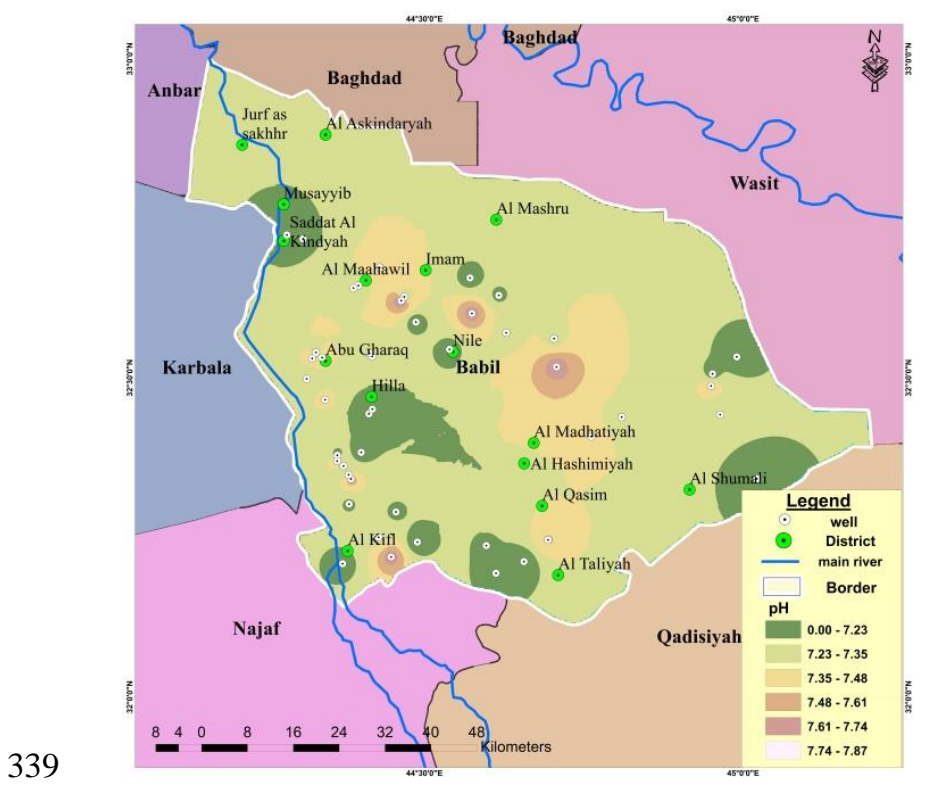

Fig. 5 pH Spatial distribution map (Singh et al., 2018).

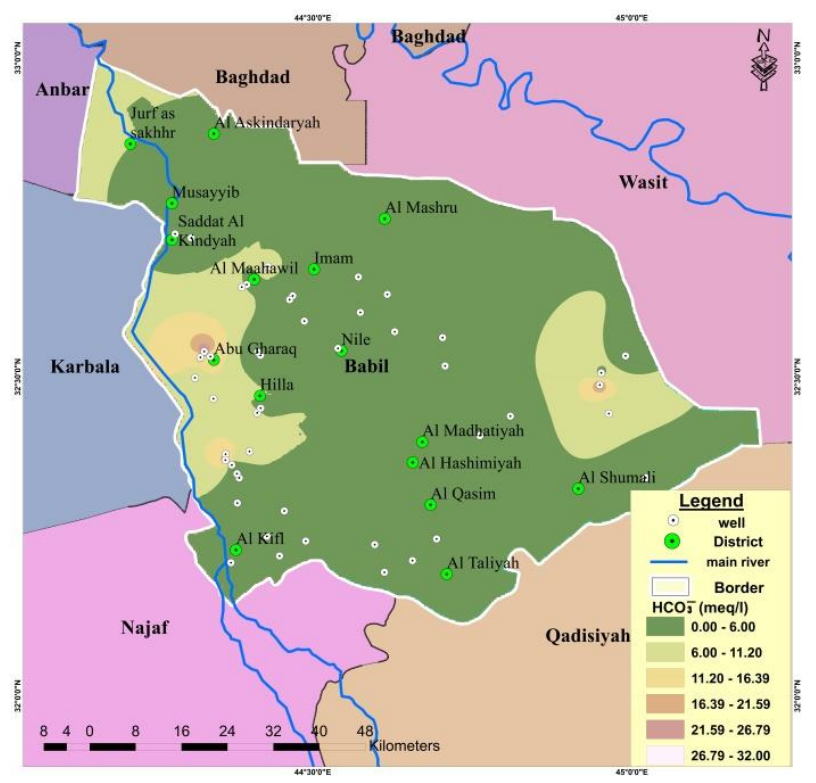

Fig. $6 \mathrm{HCO}_{3}^{-}$Spatial distribution map

- Figure (7) shows the spatial distribution from the electrical conductivity (EC) tests. The results revealed considerable differences in the EC values from $910 \mu \mathrm{s} / \mathrm{cm}$ to $24500 \mu \mathrm{s} / \mathrm{cm}$. This wide range can be attributed to the predominant activities of humans in the region. High EC values can be due to reducing the osmotic plant activity, which interferes with water and nutrient absorption from the soil (Rao, 1986). According to Wilcox's classification of water using EC, adopted by the US Department of Agriculture (Richards, 1954), above $50 \%$ of groundwater sources present in the study region are inappropriate for irrigation purposes (World Health Organization, 1993). While the remaining percentage is doubtful, as shown in Table 8

Table 8 Classification of Groundwater for Irrigation based on Electrical Conductivity (Singh et al., 2018)

\begin{tabular}{ccc}
\hline EC $\boldsymbol{\mu s} / \mathbf{c m}$ & Water class & Remark on quality \\
\hline$<250$ & Low salinity & Excellent \\
$250-750$ & Medium salinity & Good \\
$750-2250$ & High salinity & Doubtful \\
$>2250$ & Very high salinity & Unsuitable \\
\hline
\end{tabular}

- Figure (8) shows the spatial distribution map of the sodium content obtained using GIS. The results showed that the percentage of $\mathrm{Na}^{+}$in the water samples was in the range of 2.219101 .4 meq/l. 


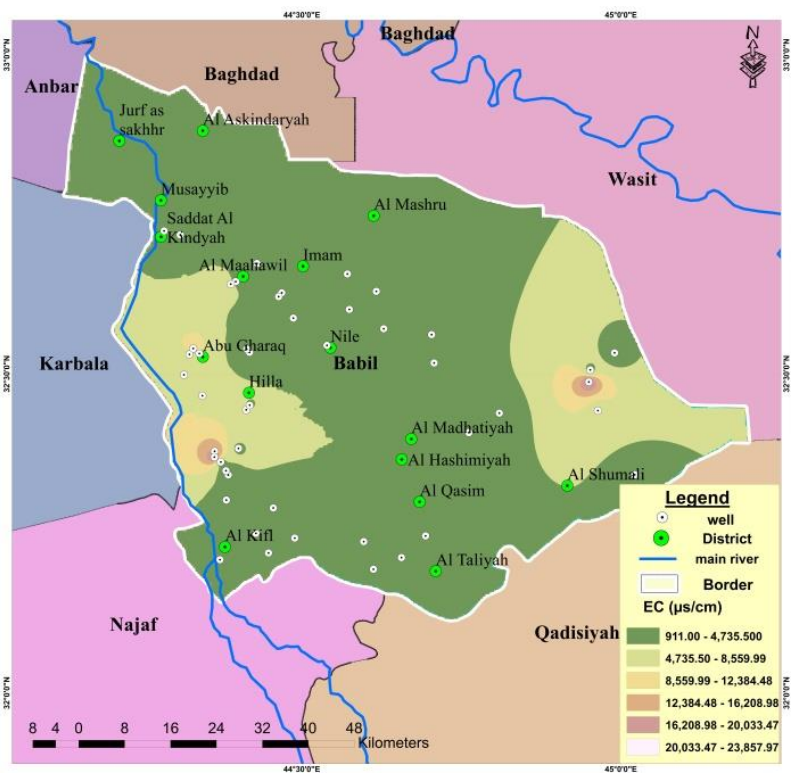

Fig. 7 EC Spatial distribution map

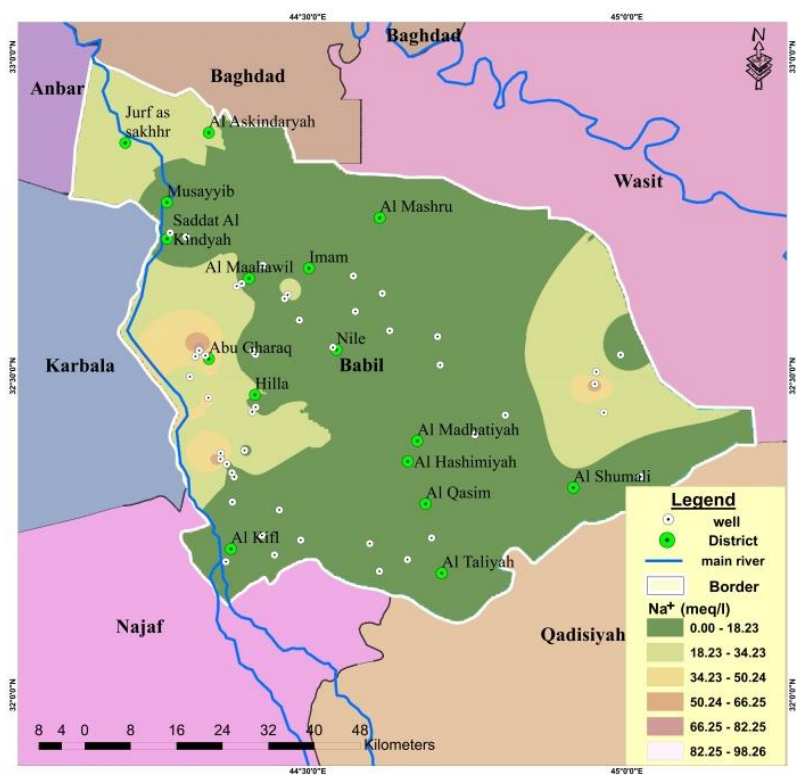

Fig. $8 \mathrm{Na}^{+}$Spatial distribution map

- In regards to the alkalinity of the ground, figure 9 shows that the SAR values for the selected water samples ranged from 1.54 to $16.34 \mathrm{meq} / \mathrm{l}$. According to Varol and Davraz (2015), groundwater is inappropriate for irrigation purposes when the SAR value is larger than 18. Table (9) presents the groundwater classification for irrigation based on the SAR (Richards, 1954). Based on the SAR limits in Table 9, all groundwater tested samples confirmed their appropriateness for irrigation.

Table 9 Classification of Groundwater for Irrigation based on SAR

\begin{tabular}{ccc}
\hline SAR values & Water class & Remark on quality \\
\hline$<10$ & Low sodium & Excellent \\
$10-18$ & Medium sodium & Good \\
$18-26$ & High sodium & Doubtful \\
$>26$ & Very high sodium & Unsuitable
\end{tabular}

- Chloride concentration does not influence the soil's physical characteristics; therefore, it is commonly not incorporated in modern water classifications. Table (2) reveals that the chloride ion concentration was in the range of $2.6226-107.1318 \mathrm{meq} / 1$ (93-3799mg/l). Figure (10) shows a relatively high chloride ion concentration in all chosen water samples. Low chloride ion concentrations are essential for plant growth, but chloride ions are toxic to sensitive plants above threshold concentrations, as shown in Table 10.

Table 10 The irrigation water classification for Chloride (Bauder et al., 2003)

\begin{tabular}{cc}
\hline Chloride $(\mathbf{m g l})$ & Effect on Crops \\
\hline Below 70 & Generally safe for all plants \\
$70-140$ & Sensitive plants show injury \\
$141-350$ & Moderately tolerant plants show injury \\
Above 350 & Can cause severe problems \\
\hline
\end{tabular}
tolerant in $35 \%$ of the samples. Moreover, $60 \%$ of the water samples could cause severe problems for plants due to the amount of chloride. 


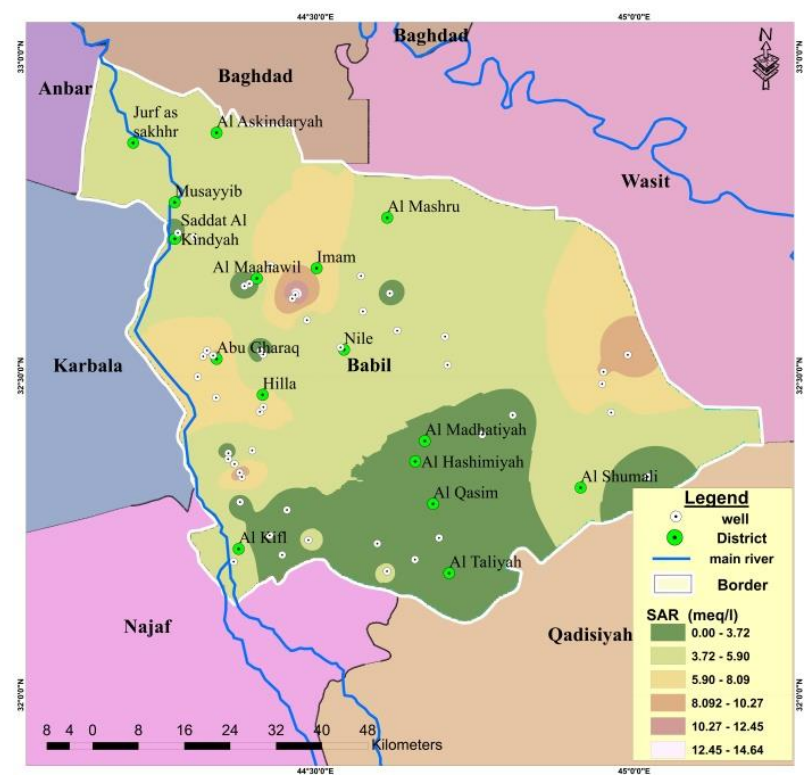

Fig. 9 SAR Spatial distribution map

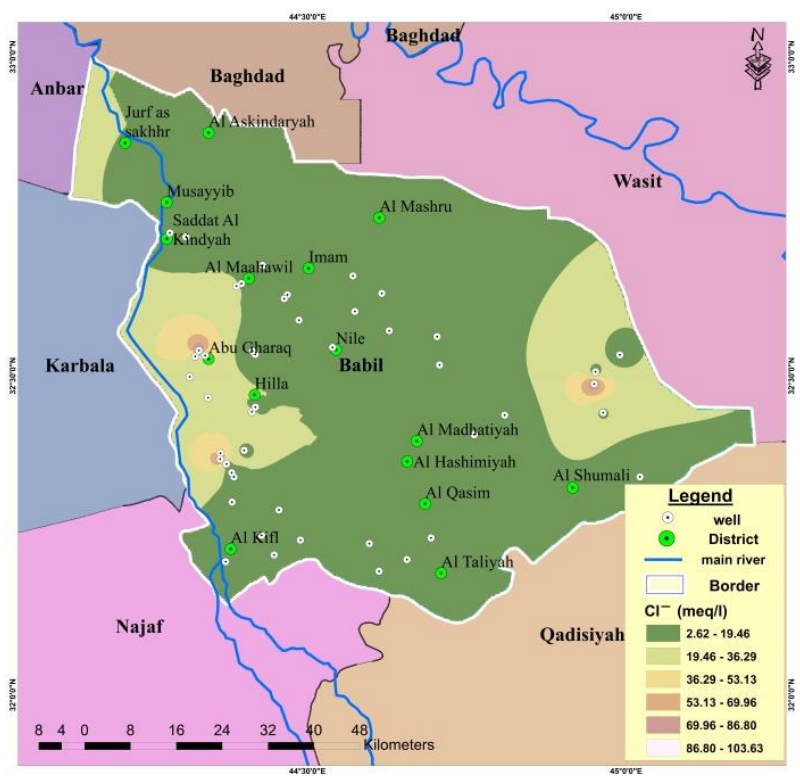

Fig. $10 \mathrm{CL}^{-}$Spatial distribution map

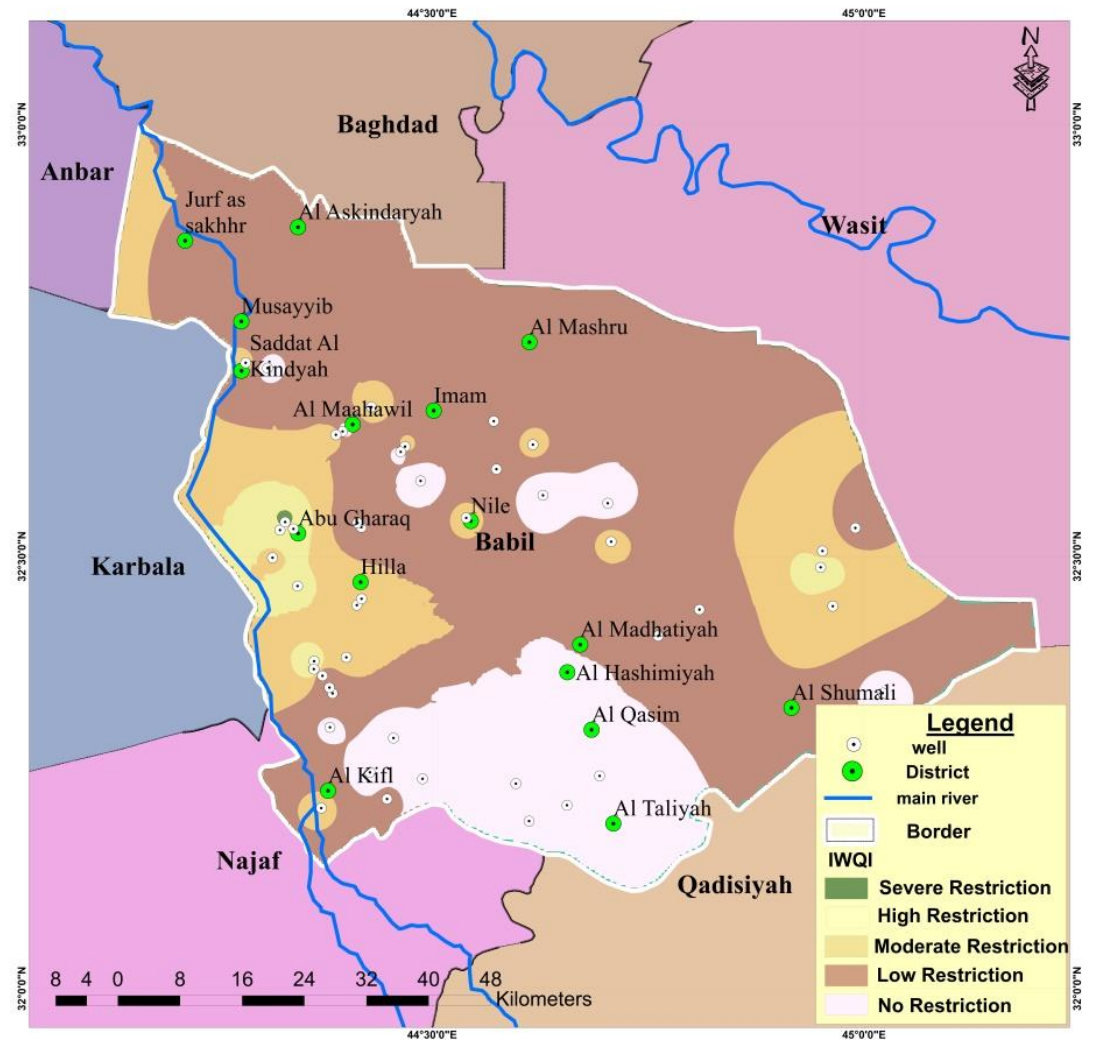

Fig. 11 IWQI Spatial distribution map

Figure 11 shows the IWQI index map resulting from integrating the parameters mentioned above using ArcGIS analyst extension. According to the IWQI map analysis, there are four classifications of water use restrictions on groundwater suitability for irrigation in the studied area. $20 \%$ of groundwater samples belong to the low-restricted category, which could be directly used for irrigation purposes without any treatment process. 50\% of groundwater samples belong to the moderate and high restricted category. This category indicates that the groundwater should be suitable for soils with high permeability and without compact layers due to these kinds of soils' capability to leach the salts. The remaining percentage of groundwater samples (30\%) belong to the severe restriction (SR) category, 
which is not appropriate for irrigation purposes under normal conditions. The SR category of groundwater can be used for soils with high permeability and excessive water usage to prevent salt accumulation.

It is important to note that a buffer analysis has been performed for the 49 wells, as shown in Figure (12). This analysis has been conducted to investigate whether some features need to be highlighted in the study area. The buffer analysis was applied with a radius value of $2 \mathrm{~km}$ and $5 \mathrm{~km}$, respectively. The results showed that some wells are located within a distance of 2 to $7 \mathrm{~km}$ from the river. The reason for this is due to the local perception that the river would be a good source of groundwater for the wells and would improve quality compared to other locations. This illustrates the reason for having a high number of wells near the river (Figure 12). However, the local perception is not accurate as the soil's hydraulic conductivity in that area is relatively low, according to AlMadhlom et al. (2016). In reality, as shown in Figures 4 and 11, the best groundwater quality for irrigation and drinking was in areas located around the central zone of the province. This illustrates that there are many parameters that affect the groundwater quality such as hydraulic conductivity, soil type and the topography, and all of them must be investigated cautiously (Al-Madhlom et al., 2016).

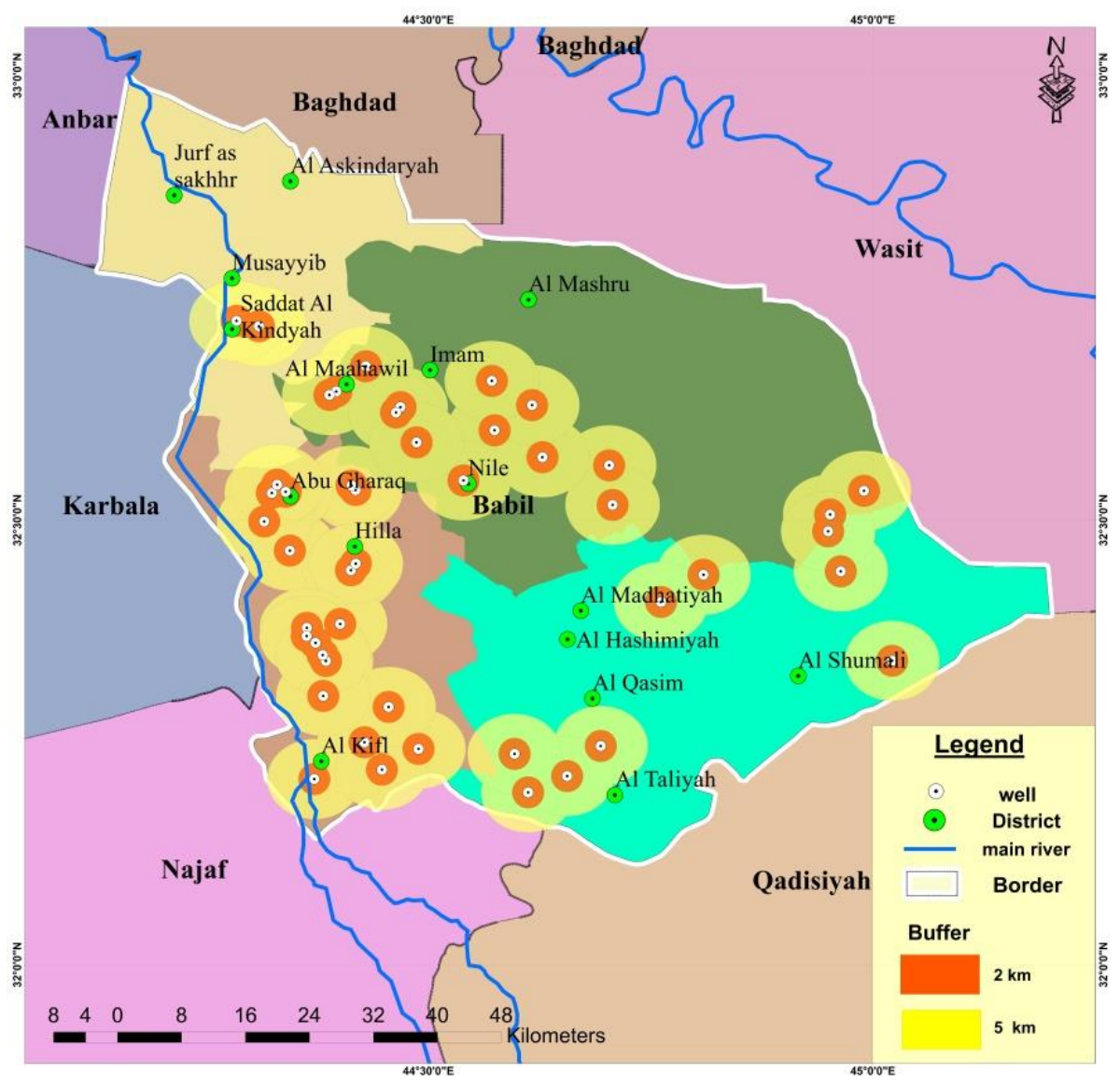

Fig. 12 Buffer map around each well

Other indices were used to evaluate the suitability of groundwater for irrigation purposes namely, Permeability Index (PI), Soluble Sodium Percentage (SSP), Kelly's ratio (KR) and Residual Sodium Carbonate (RSC). ArcGIS is used to produce maps showing the variation of all the indices mentioned above. The groundwater suitability for irrigation can be evaluated using Kelly's Ratio (Kelly, 1951). Kelly's ratio represents the ratio of sodium versus calcium and sodium versus magnesium. According to Reddy (2013), many studies have adopted Kelly's ratio to assess groundwater's suitability for irrigation purposes. When Kelly's ratio is less than or equal to one, it indicates 
that water quality is good, when the ratio is higher, the groundwater is not suitable for agricultural purposes because of high alkalinity (Karanth, 1987). Figure 13 shows that $30 \%$ of the wells are inappropriate for irrigation use because of the alkalinity and $70 \%$ of the wells contain water with good quality.

When the Residual Sodium Carbonate (RSC) value is less than $1.25 \mathrm{meq} / 1$, it indicates safe water quality, but above $2.5 \mathrm{meq} / \mathrm{l}$, it indicates the water is generally inappropriate for irrigation uses. When the RSC is in the range 1.25-2.5 meq/l, it indicates that the water is slightly appropriate for irrigation (Singha and Pasupuleti, 2020). The results shown in Figure 14 reveal that the RSC values for all samples are less than $1.25 \mathrm{meq} / \mathrm{l}$, indicating that the whole study area is within the safe limit for irrigation.

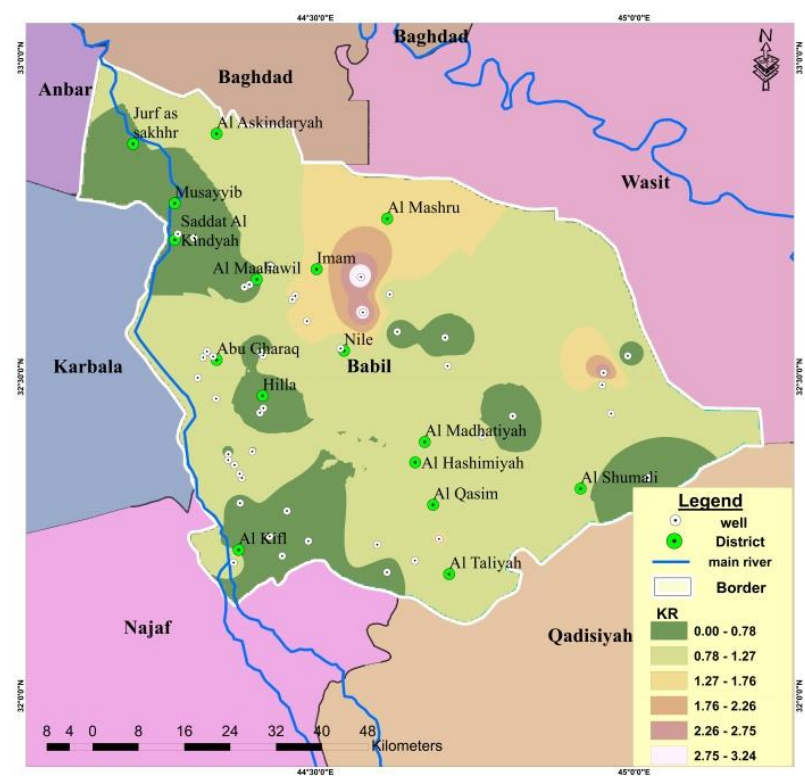

Fig. 13 KR Spatial distribution map

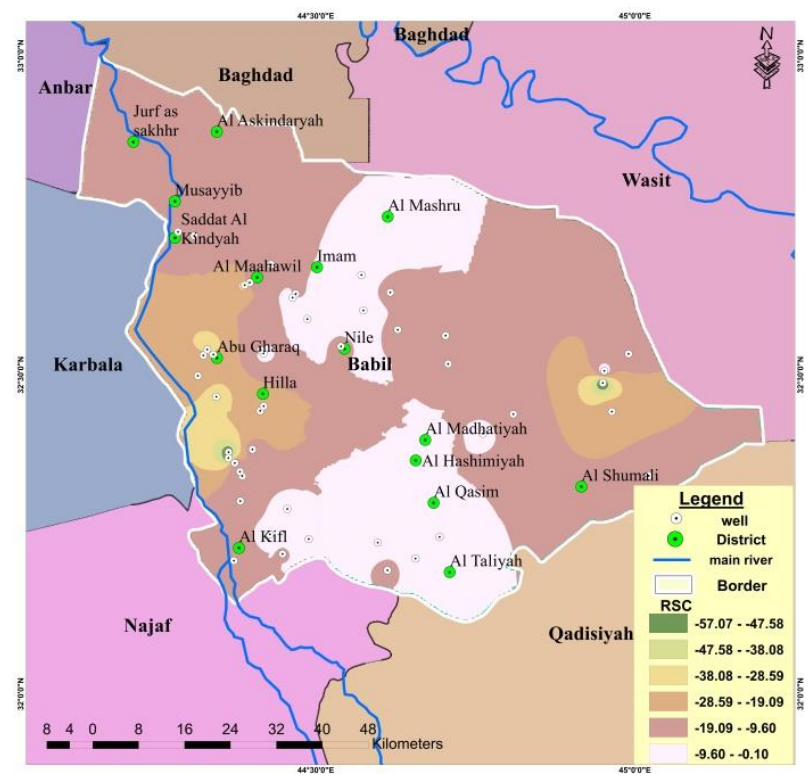

Fig. 14 RSC Spatial distribution map

A classification scheme for rating irrigation waters was proposed by Wilcox (1955) based on soluble sodium percentage (SSP). When the SSP values are higher than 50, it indicates that the water is not safe for irrigation purposes. Nevertheless, when SSP is less than 50, it indicates the water is safe (Richards, 1954). The results presented in Figure (15) showed that $30 \%$ of the study area's water samples are not safe for irrigation purposes and the remaining percentage $(70 \%)$ are good quality water.

When the Permeability Index (PI) value is less than 25, it indicates that the nature of water is unsuitable for irrigation. In contrast, water quality is suitable for irrigation when PI ranges from 25-75 and excellent water quality when PI is higher than 75. Figure (16) shows the map of the PI variation of the water samples obtained and shows that the quality of water in the area of study is appropriate for irrigation uses. 


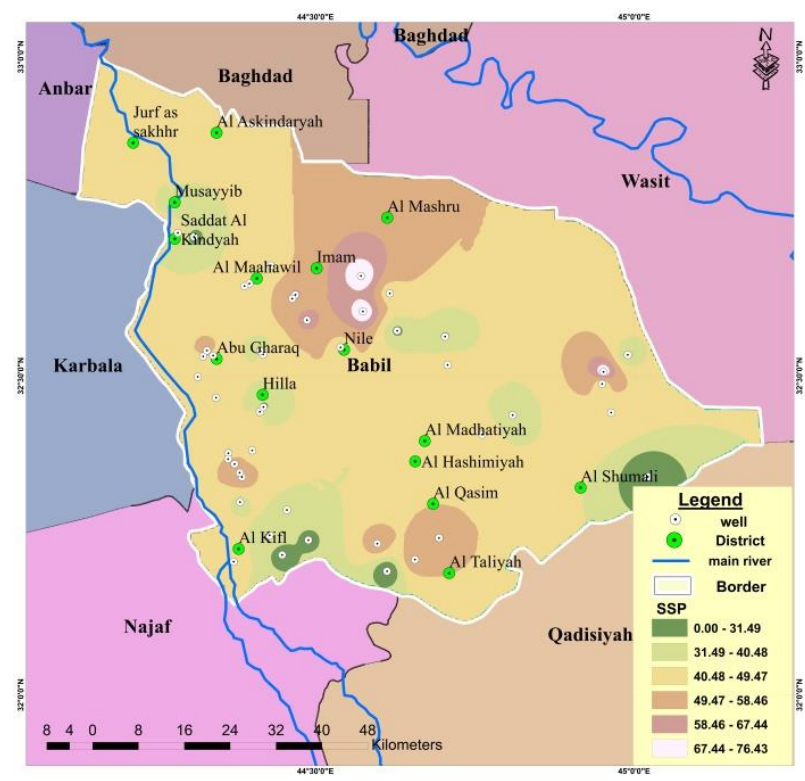

Fig. 15 SSP Spatial distribution map

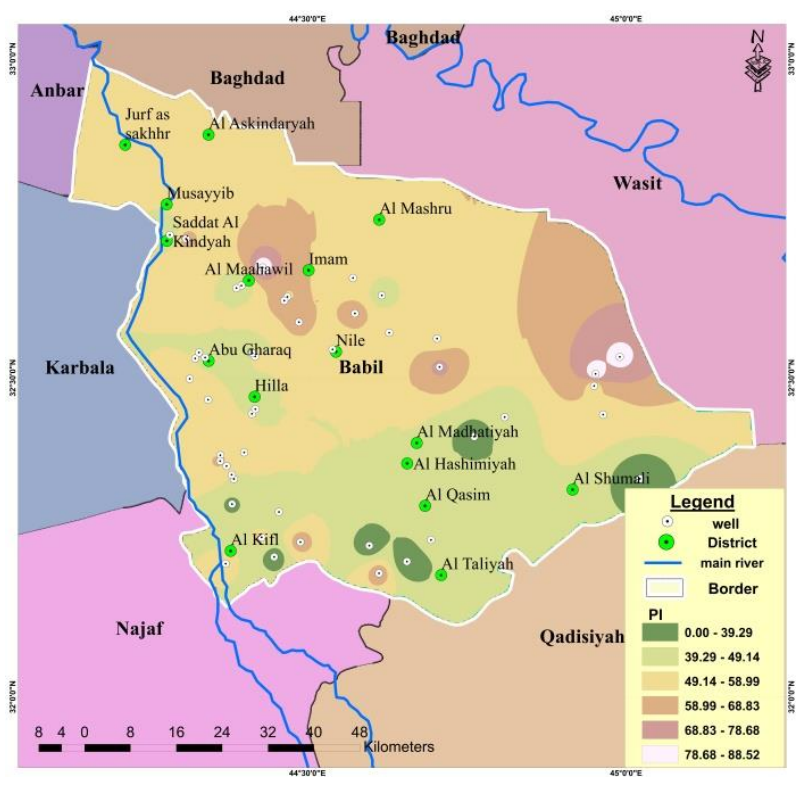

Fig. 16 PI Spatial distribution map

As shown in figures 15 and 16, the values of the SSP and PI are relatively close. However, the percentage of the suitable groundwater samples for irrigation purposes was quite different due to the differences in the classification standard for both indices. As stated above, the PI results showed that most of the groundwater samples of the study area are appropriate for irrigation use while the SSP results revealed that about $30 \%$ of the water samples are not appropriate for irrigation (Figure 17). Thus, conducting a comparison between the two indices might be able to provide more information in order to perform an accurate evaluation. Figure 17 showed that $70 \%$ of the wells have suitable groundwater quality for irrigation use based on the PI index and the SSP index. However, the high values of the PI at some wells are accompanied by high SSP values and affect groundwater quality. Although the PI index is in the excellent category at some wells, it is still crucial to investigate the SSP at the same locations. Singh et al. (2015), demonstrate that $\mathrm{Ca}^{+2}, \mathrm{Na}^{+}, \mathrm{Mg}^{+2}$, and $\mathrm{HCO}_{3}{ }^{-}$concentration can influence soil permeability profile. Therefore, these ions are used to evaluate the water PI and quality, as mentioned earlier in Equation 8. Likewise, Xu et al. (2019) suggested that the high PI values correlate with high bicarbonate and sodium ions in the groundwater. Nevertheless, Singh et al. (2020) pointed out that the percentage of soluble sodium (SSP) is essential for classifying irrigation water in terms of soil permeability. This is due to the fact that sodium-ions in irrigation water can be exchanged with $\mathrm{Mg}^{+2}$ and $\mathrm{Ca}^{+2}$ ions from the clay particles leading to reduce soil permeability. The reduction of soil permeability would affect the internal drainage and hardening of soil, which negatively impacts soil quality and seedling emergence. Generally, when the average value of both indices (SSP and PI) varies from 25 to 50, then the quality of the groundwater at that location will be suitable for irrigation in terms of PI and SSP assessment (Figure 18).

Generally, the dissolved ionic species in the groundwater represent the resultant product that is accomplished due to the weathering of rock-forming minerals and a minor contribution from atmospheric precipitation and anthropogenic activities. Moreover, as a result of the assessment for groundwater quality, it is crucial to remark that there is no significant relationship between groundwater quality and general land use. Therefore, the case study's low water quality could be attributed to mismanagement practices such as poor waste management and poor farm management practices. 


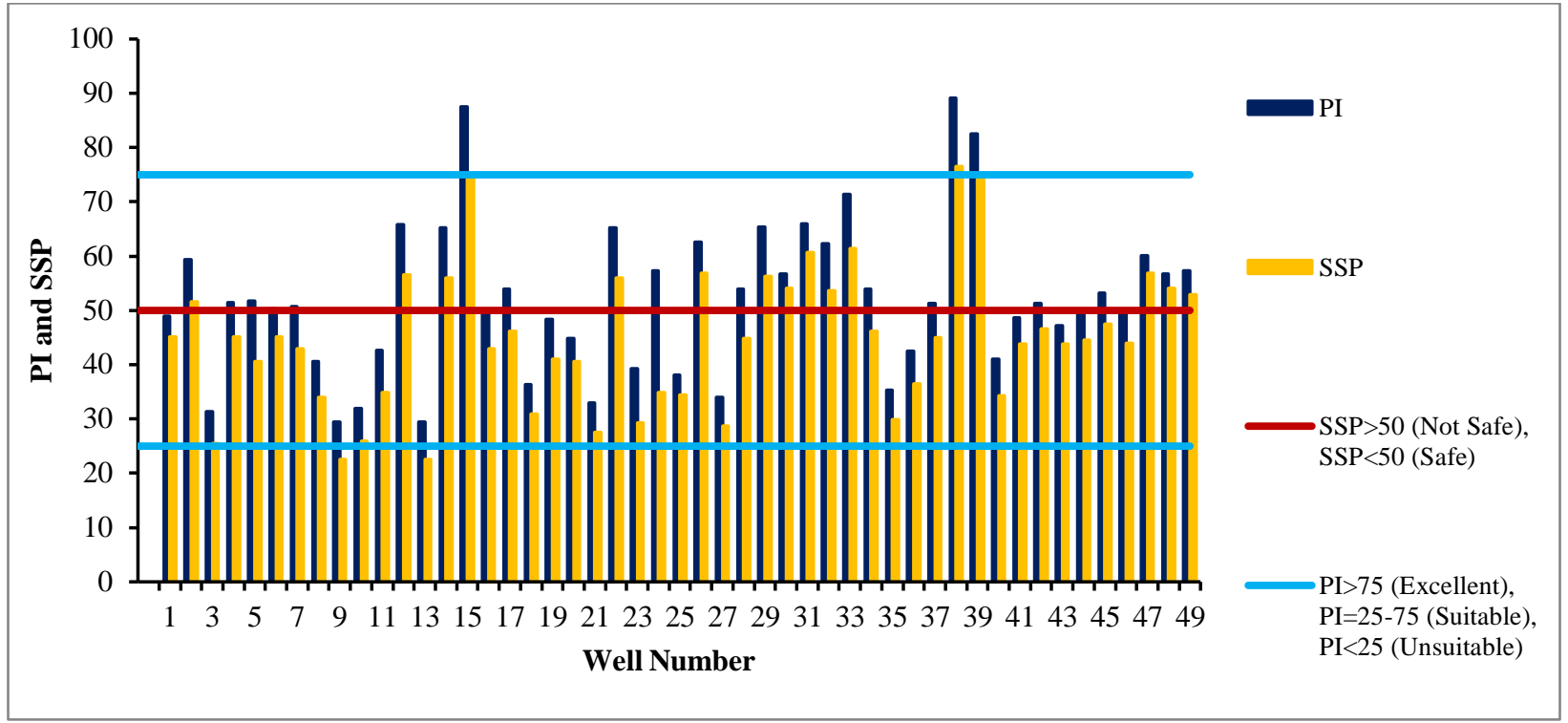

Fig. 17 Comparison between SSP and PI

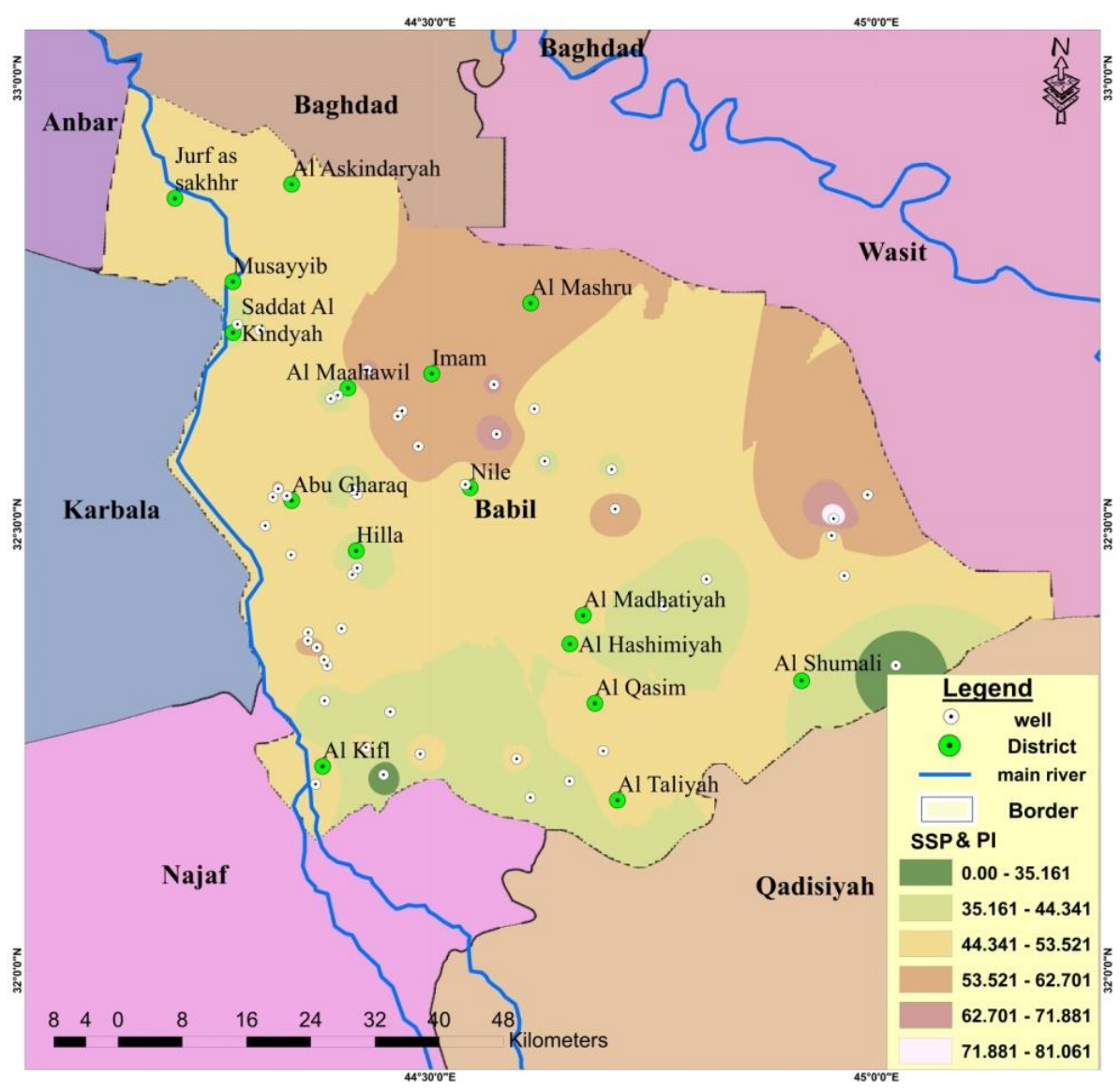

Fig. 18 Spatial distribution map between SSP and PI

\section{Conclusions}

In this paper, an assessment of the quality of the groundwater of Babylon province was conducted to explore the feasibility of using it for drinking and irrigation purposes. The data was collected from 49 wells widely distributed across the province. Taking into consideration the research limitations, the following conclusions can be drawn: 
1- According to WHO standards, around $78 \%$ of the samples collected can be used for drinking. The potable groundwater is mainly concentrated in the middle of the province. This would encourage the local government to establish the required infrastructure to invest in groundwater.

2- The groundwater of Babylon province could be used for irrigation purposes with precautions to account for the following factors:

- A relatively low pH across the sample region could make the soil harmful to plants by increasing manganese and ammonium salt concentrations' solubility.

- In general, the bicarbonate ions $\left(\mathrm{HCO}_{3}^{-}\right)$concentration is higher than the ideal concentration (1.5meq/l.).

- According to the US Department of Agriculture standards, high electrical conductivity was recorded for about $50 \%$ of the groundwater samples, making it inappropriate for irrigation purposes.

- High sodium $\mathrm{Na}^{+}$percentage, if used for irrigation, would result in more dense and rigid soil.

- The SAR ratio obtained from the samples indicates a medium to high sodium concertation, which is appropriate for irrigation but not ideal. Also, SSP values showed that $30 \%$ of the water samples tested are not safe for irrigation. Meanwhile, the Permeability Index (PI) results showed that water quality in the study area is appropriate for irrigation use.

This study is limited to the locations of existing wells and the methods used for data collection. The results can be used to monitor groundwater quality in this region and for comparison across central Iraq since the soil characteristics are geographically reasonably consistent. This study's outcomes can help provide guidelines for the authorities in managing groundwater quality and developing future improvement interventions. Nevertheless, if the authorities decided to use groundwater for irrigation purposes, more detailed testing is required to identify effective treatment processes.

Based on the data presented here, more industrial and agricultural practice regulation is required in this region. The governmental authorities face many challenges implementing new legislations, including the financial support for groundwater extraction and quality control. Challenges also exist at the societal level where the local people's cooperation to adopt new practices requires the government to run education programmes to disseminate the required social awareness. Many countries around the world have an adequate level of knowledge and experience dealing with groundwater. Lessons from other parts of the world where groundwater extraction is successfully run could be adopted as part of the government's national strategy going forward.

\section{Acknowledgements}

The authors would like to acknowledge that some of the water sample data has been kindly supplied by the Water Resources Ministry in Iraq.

\section{References}

Abbasnia, A., Radfard, M., Mahvi, A. H., Nabizadeh, R., Yousefi, M., Soleimani, H., \& Alimohammadi, M. (2018). Groundwater quality assessment for irrigation purposes based on irrigation water quality index and its zoning with GIS in the villages of Chabahar, Sistan and Baluchistan, Iran. Data in brief, 19, 623-631.

Alam, W., Singh, K. S., Gyanendra, Y., Laishram, R. J., and Nesa, N. (2020). Hydrogeochemical assessment of groundwater quality for few habitations of Chandel District, Manipur (India). Applied Water Science, 10(5), 1-13. 
Alanbari, M., Alazzawi, H., Al-Ansari, N., and Knutsson, S. (2015). Environmental Assessment of Al-Hilla City Wastewater Treatment Plants. Journal of Civil Engineering and Architecture, 9(6), 749-755.

Al-Jubouri, S. M., and Holmes, S. M. (2020). Immobilisation of cobalt ions using hierarchically porous 4A zeolite-based carbon composites: Ion-exchange and solidification. Journal of Water Process Engineering, 33, 101059.

Al-Madhlom, Q., Al-Ansari, N., and Hussain, H. M. (2016). Assessment of Groundwater Vulnerability in Northern Babylon Governorate, Iraq. Engineering, 8(12), 883-902.

APHA. (1998). 'Standard Methods for the Examination of water and wastewater', American Public Health Association, Washington D. C., 1000p.

Ayers, R. S., and Westcot, D. W. (1985). Water quality for agriculture (Vol. 29). Food and Agriculture Organization of the United Nations, Rome.

Ayers, R.S., and Westcot, D.W. (1994). Water quality for agriculture: Irrigation and Drainage Paper 29, Revision 1, 1-130, Food and Agriculture Organization of the United Nations, Rome.

Bachmann, A., Virginia, T., Al-Obeidi, L. A., and Kilıç, D. T. (2019). Tigris-Euphrates River Ecosystem: A Status Report.

Backman, B., Bodiš, D., Lahermo, P., Rapant, S., and Tarvainen, T. (1998). Application of a groundwater contamination index in Finland and Slovakia. Environmental Geology, 36(1-2), 55-64.

Bauder, T. A., Waskom, R. M., and Davis, J. G. (2003). Irrigation water quality criteria. Colorado State University Cooperative Extension.

Bernardo, S., Soares, A. A., and Mantovani, E. C. (1995). Manual of irrigation. Vicosa: UFV, 488p.

Brown, R. M., McClelland, N. I., Deininger, R. A., and O'Connor, M. F. (1972). A water quality index-crashing the psychological barrier. In Indicators of environmental quality (pp. 173-182). Springer, Boston, MA.

Buday, T., and Jassim, S. Z. (1980). Regional Geology of Iraq: Vol. 1. Stratigraphy and Paleogeography, Iraq State Organization for minerals, Baghdad, 445pp.

Cude, C. G. (2001). Oregon water quality index a tool for evaluating water quality management effectiveness 1 . JAWRA Journal of the American Water Resources Association, 37(1), 125-137.

ESRI, A. (2015). 10.5: Using ArcGIS Spatial Analyst. Software User Guide ESRI, USA.

Husain, T. (1998). Application of the National Water Quality Index prototype in Newfoundland. Prepared for State of the Environment Task Group, Canadian Council of Ministers of the Environment.

Iraq National Population Commission. (2012). Iraq Population Situation Analysis Report.

United Nations Report for Iraq, (2013). Water in Iraq Factsheet, Iraq Joint Analysis and Policy Unit. https://www.iraqicivilsociety.org//wp-content/uploads/2014/02/Water-Factsheet.pdf (accessed 4th Jan 2021)

IAU, Babil Governorate Profile (2010), https://reliefweb.int/sites/reliefweb.int/files/resources/CC0511E38D021F8BC12577EC00311F9EFull_Report.pdf, (accessed 4th Jan 2021)

Jerome, C., and Pius, A. (2010). Evaluation of water quality index and its impact on the quality of life in an industrial area in Bangalore, South India. American Journal of Scientific and industrial research, 1(3), 595-603.

Karanth, K. R. (1987). Ground water assessment: development and management. Tata McGraw-Hill Education. New Delhi, India

Kelly, WP. (1951). Alkali soils-Their formation properties and reclamation. 3rd edition. Reinhold Publication, New York, USA, p 92. 
Khan, F., Husain, T., and Lumb, A. (2003). Water quality evaluation and trend analysis in selected watersheds of the Atlantic region of Canada. Environmental Monitoring and assessment, 88(1-3), 221-248.

Khan, T. A., and Abbasi, M. A. (2013). Synthesis of parameters used to check the suitability of water for irrigation purposes. International journal of environmental sciences, 3(6), 2131-2138.

Madhloom, H. M., and Al-Ansari, N. (2018). Geographical information system and remote sensing for water resources management case study: The Diyala River, Iraq. International Journal of Civil Engineering and Technology, 9(12), 971984.

Meireles, A. C. M., Andrade, E. M. D., Chaves, L. C. G., Frischkorn, H., and Crisostomo, L. A. (2010). A new proposal of the classification of irrigation water. Revista Ciencia Agronomica, 41(3), 349-357.

Michael, A. M. (1978). Irrigation: theory and practice. Vikas publishing house.

Ministry of Environment. (1998). System Maintenance of River and Public Water Pollution in Iraq.

Ministry of Planning and Development Cooperation. (2010). [Standard No. (417) for drinking water (second update 2009)]. Baghdad: Ministry of Planning and Development Cooperation; Arabic.

Mohammed, W. T., Abdullah, S. M., and Ghalib, A. M. (2007). Catalytic wet oxidation of phenol in a trickle bed reactor. Iraqi Journal of Chemical and Petroleum Engineering, 8(4), 45-52.

Nelly, K. C., and Mutua, F. (2016). Ground Water Quality Assessment Using GIS and Remote Sensing: A Case Study of Juja Location, Kenya. American Journal of Geographic Information Systems, 5(1), 12-23.

Quddus, K. G. (1996). Irrigation water quality in some selected villages of Meherpur in Bangladesh. Bangladesh J. Agric. Sci., $23,51-57$

Raghunath, IM (1987). Groundwater. 2nd Edn., Wiley Eastern Ltd., New Delhi, India.

Raihan, F. and Alam, J.B. (2008). Assessment of groundwater quality in sunamganj Bangladesh Iranian. J. Environ. Health Sci. Eng., v. 6(3), pp.155-166.

Rao, N. S. (1986). Hydrogeology and hydrogeochemistry of Visakhapatanam, Ph. D Thesis unpublished, Department of Geology, Andhra University, Visakhapatnam, India.

Reddy, K. S. (2013). Assessment of groundwater quality for irrigation of Bhaskar Rao Kunta watershed, Nalgonda District, India. International Journal of Water Resources and Environmental Engineering, 5(7), 418-425.

Reyes-Toscano, C. A., Alfaro-Cuevas-Villanueva, R., Cortés-Martínez, R., Morton-Bermea, O., Hernández-Álvarez, E., Buenrostro-Delgado, O., and Ávila-Olivera, J. A. (2020). Hydrogeochemical characteristics and assessment of drinking water quality in the urban area of Zamora, Mexico. Water, 12(2), 556.

Richards, L. A., (1954). Diagnosis and Improvement of Saline and Alkaline Soils, Agricultural Handbook No. 60 (Washington, D.C. United States Department of Agriculture)

Sarkar, A. A. and Hassan, A. A. (2006) Water quality assessment of a groundwater basin in Bangladesh for irrigation use. Pak. J. Biol. Sci., v.9(9), pp.1677-1684.

Singh, K. K., Tewari, G., and Kumar, S. (2020). Evaluation of Groundwater Quality for Suitability of Irrigation Purposes: A Case Study in the Udham Singh Nagar, Uttarakhand. Journal of Chemistry, 2020.

Singh, P. K., Atal, S., and Dubey, S. K. (2018). Assessment of shallow groundwater quality for irrigation in parts of Agra District, Uttar Pradesh, India. Earth Science India, 11(3), 133-148. https://doi.org/10.31870/esi.11.3.2018.09 
Singh, S. K., Srivastava, P. K., Singh, D., Han, D., Gautam, S. K., and Pandey, A. C. (2015). Modeling groundwater quality over a humid subtropical region using numerical indices, earth observation datasets, and X-ray diffraction technique: a case study of Allahabad district, India. Environmental geochemistry and health, 37(1), 157-180.

Singha, S. S., and Pasupuleti, S. (2020). Hydrogeochemical modeling based approach for evaluation of groundwater suitability for irrigational use in Korba district, Chhattisgarh, Central India. SN Applied Sciences, 2(9), 1-13.

Singha, S., Devatha, C. P., Singha, S., and Verma, M. K. (2015). Assessing Ground Water Quality using GIS. International Journal of Engineering Research \& Technology, 4(11), 689-694.

Singha, S., Pasupuleti, S., Singha, S and Villuri, V.G.K. (2017). An integrated approach for evaluation of groundwater quality in Korba district, Chhattisgarh using Geomatic techniques. Journal of Environmental Biology, 38(5), p.865-872. DOI: $10.22438 /$ jeb/38/5/MRN-600

Talukder, M. S. U., Shirazi, S. M., and Paul, U. K. (1998). Suitability of groundwater for irrigation at Kirimganj Upazila Kishoreganj. Progress Agric, 9(1-2), 107-112.

Todd, D.K. (1995). Groundwater hydrology. 3rd Edn., Wiley and Sons Inc., New York, U.S., 625p.

Richards, L. A., (1954). Diagnosis and Improvement of Saline and Alkaline Soils, Agricultural Handbook No. 60 (Washington, D.C. United States Department of Agriculture)

Varol, S., and Davraz, A. (2015). Evaluation of the groundwater quality with WQI (Water Quality Index) and multivariate analysis: a case study of the Tefenni plain (Burdur/Turkey). Environmental Earth Sciences, 73(4), 1725-1744.

Wilcox, L.V. (1955). Classification and use of irrigation water, USA Dept. Ag. Circ. 696, Washington DC. 19p.

World Health Organization. (1993). Guidelines for drinking-water quality. World Health Organization (WHO), Geneva, Switzerland.

World Health Organization. (2004). Information Products: Water, Sanitation and Health. World Health Organization (WHO), Geneva, Switzerland.

Xu, P., Feng, W., Qian, H., and Zhang, Q. (2019). Hydrogeochemical characterisation and irrigation quality assessment of shallow groundwater in the central-western Guanzhong basin, China. International journal of environmental research and public health, 16(9), 1492.

Yacoub, S. Y. (2011). Stratigraphy of the Mesopotamia plain. Iraqi Bulletin of Geology and Mining, (4), 47-82.

Zandbergen, P. A., and Hall, K. J. (1998). Analysis of the British Columbia water quality index for watershed managers: A case study of two small watersheds. Water Quality Research Journal, 33(4), 519-550.

Zektser, I. S., and Everett, L. G. (2004). Groundwater resources of the world and their use. IHP-VI Ser. Groundwater 6, U. N. Educ., Sci. and Cultural Organ., Paris 